\title{
Скифские сюжеты и мотивы в традиционном и современном ювелирном искусстве Тувы
}

\author{
Жанна Э. Айжы, Яна А. Нан-Хоо \\ Национальный музей им. Алдан-Маадыр Республики Тыва, Российская Федерация
}

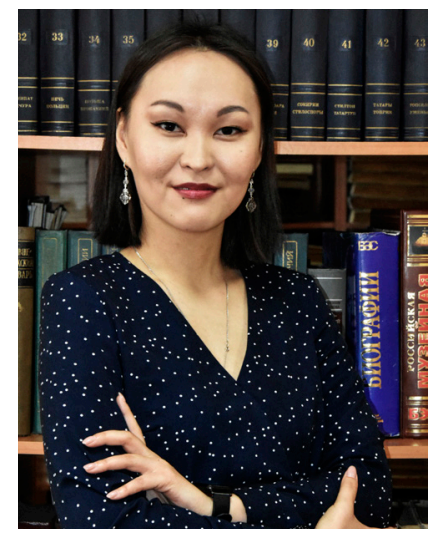

В статье рассмотрены некоторые особенности традиционного ювелирного искусства Тувы и проанализированы работы современных представителей отрасли, следующих стилистике и иконографии скифо-сибирского звериного стиля.

Рассмотрены наиболее распространенные ювелирные изделия тувинцев - мастеров рубежа XIX-XX вв. (серьги, перстни, фигурные поясные бляхи, накосные украшения), которые хранятся и экспонируются в Национальном музее Республики Тыва (1131 единии украшений). Сделан вывод, что преемственность с искусством эпохи ранних кочевников прослеживается мало: сохранились трансформированный под растительный узор зооморфный орнамент (кошкар мыйызы) и растительный мотив (чечектеп) в виде многолепестковой цветочной розетки, берущие свои истоки в искусстве древних скифов.

Скифо-сибирский стиль стал специально возрождаться в современном ювелирном искусстве Тувы с 2000-х г2. и это было связано с открытием в Национальном музее Тувы постоянной экспозиции, что позволило ювелирам, также как и другим посетителям, ознакомиться с украшениями царской четы и знати из курганов Аржан и Аржан-2. Из современных тувинских ювелирных работ были изучены произведения мастеров Вене-

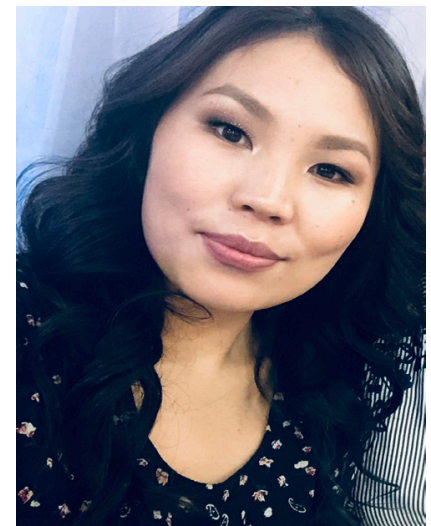
ры Никулиной, Айбеса Олчей и Елены Седип. В их работах (из серебра, золота, бисера и пр.) органично переплелись национальные тувинские традиции по художественной обработке металла и по-новому осмысленные скифские сюжеты и мотивы. С одной стороны, в ювелирных изделиях прослеживается использование стилистических элементов скифского стиля, с другой стороны - звериные скифские образы смело накладываются на современные тренды в ювелирном искусстве (например, в работах мастера по бисеру Елены Седип). Анализ их ювелирных украшений позволяет говорить о формировании нового направления в современном ювелирном искусстве Тувы, в котором по-новому осмысливаются древние образы и мотивы.

Ключевые слова: скифо-сибирский звериный стиль; ювелирное дело; тувинское искусство; Тува; тувинцы; скифский образ; звериный стиль; традиционное искусство; неотрадиционализм

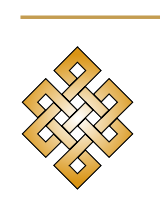

Для цитирования:

Айжы Ж. Э., Нан-Хоо Я. А. Скифские сюжеты и мотивы в традиционном и современном ювелирном искусстве Тувы // Новые исследования Тувы. 2021, № 1. C. 73-90. DOI: https://www.doi.org/10.25178/nit.2021.1.4

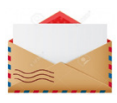

Айжы Жанна Эдуардовна - старший научный сотрудник отдела культуры, искусства и религии Национального музея им. Алдан-Маадыр Республики Тыва. Адрес: 667000, Россия, г. Кызыл, ул. Титова, д. 30. Тел: +7 (394) 223-43-28. Эл. адрес: ayzhy94@mail.ru

Нан-Хоо Яна Александровна - научный сотрудник отдела культуры, искусства и религии Национального музея им. Алдан-Маадыр Республики Тыва. Адрес: 667000, Россия, г. Кызыл, ул. Титова, д. 30. Тел: +7 (394) 223-43-28. Эл. адрес: уаnа. nankhoo.1993@mail.ru

AYZHY, Zhanna Eduardovna, Senior Research Fellow, Department of Culture, Art and Religion, Aldan Maadyr National Museum of the Republic of Tuva. Postal address: 30 Titova St., 667000 Kyzyl, Russia. Tel.: +7 (394) 223-43-28. Email: ayzhy94@mail.ru ORCID ID: 0000-0002-6217-2866

NAN-KHOO, Yana Aleksandrovna, Research Fellow, Department of Culture, Art and Religion, Aldan Maadyr National Museum of the Republic of Tuva. Postal address: 30 Titova St., 667000 Kyzyl, Russia. Tel.: +7 (394) 223-43-28. Email: yana. nankhoo.1993@mail.ru ORCID ID: 0000-0002-3998-7522 


\title{
Scythian motifs and imagery in traditional and contemporary jewelry art in Tuva
}

\author{
Zhanna E. Ayzhy, Yana N. Nan-Khoo \\ Aldan Maadyr National Museum of the Republic of Tuva, Russian Federation
}

\begin{abstract}
The article examines a number of features of traditional art of jewelry art of Tuva. Also analyzed are the works of contemporary jewelry artists who explore the iconography and follow the style of the Scythian-Siberian animal style.

The article looks at the most widespread types of Tuvan jewelry of the turn of the 20th century - earrings, signet rings, ornamental best plates and braid decorations, which are preserved and exhibited at the National Museum of the Republic of Tuva (1131 items all in all). The authors conclude that little continuity can be traced between early nomadic art and that of late 19th and early 20th century. Among the surviving traditions are the koshkar myiyzy zoomorphic ornament (transformed to feature a floral ornament) and the chechektep plant motif as a multifoil rosette, both stemming back to the art of ancient Scythians.

Since the 2000s, the Scythian-Siberian style has seen a conscious revival, largely due to the opening of a permanent exposition at the National Museum which familiarized jewellers, as well as other visitors, with the treasures of the royal couple and the aristocracy from Arzhan and Arzhan II mounds. Of contemporary Tuvan artists, a special focus is made on Venera Nikulina, Aibes Olchei, and Yelena Sedip. Their works of silver, gold, beads and other materials organically combine ethnic Tuvan stylistic traditions and daring attempts of applying the Scythian animal style to the contemporary trends in jewelry art (as they, e.g., appear in the bead art of Yelena Sedip). Their jewelry is found to be part of a new trend in the art of contemporary Tuva, the trend which provides a new interpretation of the ancient imagery and motifs.
\end{abstract}

Keywords: Scythian-Siberian animal style; jewelry art; Tuvan art; Tuva; Tuvans; Scythian imagery; animal style; traditional art; neotraditionalism

\section{For citation:}

Ayzhy Zh. E. and Nan-Khoo Ya. N. Scythian motifs and imagery in traditional and contemporary jewelry art in Tuva. New Research of Tuva, 2021, no. 1, pp. 73-90. (In Russ.). DOI: https://www.doi.org/10.25178/nit.2021.1.4

\section{Введение}

Художественная обработка металла и ювелирное дело занимают особое место в декоративноприкладном искусстве тувинцев. Традиции и знания кузнечного мастерства передавались строго от отца к сыну или от дяди к племяннику, даже существовало разделение на «черных кузнецов» (кара дарган), занимающихся в основном изготовлением орудий труда из железа, чугуна и сплавов, и «сложных кузнецов» (нарын дарган), в ведение которых входила работа с драгоценными металлами и полудрагоценными камнями. Именно нарын дарган занимался ювелирным делом, изготавливая различные мужские и женские украшения, детали конского снаряжения из серебра с использованием полудрагоценных камней (Вайнштейн, 1974: 81). В XIX - начале XX в. многие путешественники, побывавшие в Туве, отмечали высокую художественную ценность произведений тувинских дарганов. В частности, Ф. Я. Кон в своих очерках дает следующую оценку работе кузнецов «... По Хемчику кузнечные изделия поражают своей красотой... Литейное искусство сохранилось тоже почти исключительно по Хемчику. Медные и бронзовые шахматы, отлитые на Хемчике, могут конкурировать с изделиями европейских мастеров» (Кон, 1936: 71).

Исходя из упоминаний разных путешественников и исследователей (Ф. Я. Кон, Г. Е. ГруммГржимайло) и многочисленных экспонатов Национального музея Республики Тыва, датируемых XIX-XXI вв., можно сделать вывод о том, что уже к концу XIX в. в Туве, а именно в западной части региона, развивались школы художественной обработки металла, в которых мастера-ювелиры знали и применяли различные техники.

В настоящее время в ювелирном искусстве Тувы прослеживаются три направления: 1) изготовление ювелирных изделий по традиционным образцам XIX-XX вв.; 2) авторские стилизованные украшения, 
выполненные по современным технологиям; 3) ювелирные работы, вдохновленные музейными экспонатами. В частности, в данной статье рассматриваются украшения, копирующие или по-новому осмысливающие предметы из скифских курганов Аржан, Аржан-2 с их последующей адаптацией к сегодняшним актуальным трендам. В тувиноведении активно исследуется декоративно-прикладное искусство тувинцев, в раздел которого входит также ювелирное дело. Однако многие авторы в целом изучают проблематику традиционной преемственности ювелирного искусства. В частности, о стилистике традиционных съемных украшений тувинских женщин пишет А. Б. Ондар (Ондар, 2017: 41-47). Также ювелирный промысел тувинцев исследуется в контексте истории и развития художественной обработки металла тюркско-монгольских народов Сибири (Москвина, Павлова, 2015).

Исследований скифо-сибирского звериного стиля в современном ювелирном искусстве тувинцев еще не производились, в том числе с учетом соотношения старых традиций и новаций. Это обусловило новизну нашей работы.

Цель статьи - рассмотреть некоторые особенности традиционного ювелирного искусства Тувы и проанализировать работы современных представителей отрасли, следующие стилистике и иконографии скифо-сибирского звериного стиля.

Актуальность работы также связана с многочисленными на данный момент исследованиями археологов, искусствоведов и историков скифо-сибирского звериного стиля в контексте общих проблем древнего искусства и идеологии, культурно-исторической области, ее генезиса, функционирования и исчезновения, ее взаимосвязей с античной и восточными цивилизациями. Все исследования, касающиеся данной тематики, можно условно разделить на две группы. Первая - это труды, посвященные искусствоведческому анализу звериного стиля (Круглова, 2020; Переводчикова, 1994; Sher, 1988). Вторая - это труды, раскрывающие региональную специфику звериного стиля в Крыму, на Кавказе, в Саяно-Алтайском регионе (Калинин, 2015; Килуновская, 1994, 2015; Канторович, 2014 ; Канторович, Яблонский, 2009; Hancar, 1952). Отдельно стоит выделить исследования, посвященные культуре тувинцев, позволяющие раскрыть своеобразие традиционного народного искусства (Иргит, 2017; Будегечиева, 1995; Вайнштейн, 1974; Дьяконова, 1960; Киселев, 1951; Кон, 1936).

В работе применяются исторический, иконографический ${ }^{1}$ и сопоставительный методы. Авторами проведен подробный анализ ювелирных изделий тувинских кузнецов XIX-XX вв. и современныХ ювелиров (время создания, материал и техника, форма, орнаментальная композиция). Анализ дополнен теоретической базой, основывающейся на фундаментальные исследования, что позволяет ответить на вопрос о преемственности между скифским звериным стилем и тувинским ювелирным искусством.

В качестве основной источниковой базы исследования в статье авторами выбраны наиболее распространенные ювелирные изделия тувинцев: серьги, перстни, фигурные поясные бляхи, накосные украшения. Рассматриваются произведения мастеров рубежа XIX-XX вв., которые хранятся и экспонируются в Национальном музее Республики Тыва2; а также изделия мастеров, которые работают в Туве в настоящее время и с работами которых авторы статьи смогли ознакомиться в г. Кызыле. В частности, работы Айбес Олчея представлены в экспозиции «Декоративно-прикладное искусство Тувы. Серебро» в Национальном музее Республики Тыва. Также в музее была открыта временная выставка произведений автора вместе с якутским ювелиром Александром Манжурьевым «Урянхай Уус. Связь времен и народов» в июне 2016 г. С ювелирными изделиями Венеры Никулиной авторы статьи ознакомились в личном архиве мастера. Произведения Елены Седип также были представлены на временной выставке «Искусство красоты» в Национальном музее Республики Тыва в марте 2020 г.

\footnotetext{
${ }^{1}$ Метод иконографии в искусствоведении используется для анализа любого художественного произведения через интерпретацию сюжета посредством смыслового содержания символики, аллегорий, образов. Художественное произведение в данном методе понимается как знак, символ определенного исторического периода или эпохи. Для подобного знака характерно не только его зрительное восприятие реципиентом, но прежде всего восприятие через культурные коды эпохи, философию, личность автора (Панофский, 2009: 34).

${ }^{2}$ Ювелирные изделия, изготовленные в середине XX в. на высоком художественном уровне, в музее почти не представлены, так как в советское время, в частности, после 1950-х гг. ремесла, связанные с изготовлением одежды, и вместе с ними и ювелирный промысел, утратил актуальность и пришел в упадок (Красавина, Балган, 2019: 695). Только с 1980-х гг. известные тувинские профессиональные художники и камнерезы С. Х. Кочаа и В. Ш. Салчак развернули широкую деятельность по восстановлению утраченных технологий в ювелирном искусстве и начали изготавливать традиционные ювелирные украшения.
} 


\section{Скифо-сибирский звериный стиль и традиционное ювелирное искусство тувинцев рубежа $\mathrm{XIX}-\mathrm{XX} в$ в.}

Многие авторы (С. И. Вайнштейн, С. В. Киселев, Т. Б. Будегечиева и др.) в своих исследованиях указывают на роль и значение искусства древних скифов на формирование тувинской художественной культуры. Именно искусство скифов во многом предопределила устойчивые эстетические и изобразительные ориентиры тувинской культуры. Например, С. И. Вайнштейн выявил, что в камнерезном искусстве тувинцев приемы изображения животных восходят к скифо-сибирскому звериному стилю (Вайнштейн, 1974: 216). Так, в мелкой пластике звериный стиль основательно закрепился, не претерпев при этом каких-либо масштабных изменений. Т. Б. Будегечиева отметила, что в целом анималистическое направление в тувинской художественной культуре связано со скифским временем (Будегечиева, 1995: 46).

А что можно сказать о скифо-сибирском зверином стиле в традиционном ювелирном искусстве тувинцев? Для исследования данного вопроса мы обратились к предметам ювелирного искусства тувинцев, представленным в экспозиции Национального музея Республики Тыва. Музей обладает наиболее репрезентативными экспонатами, собранными сотрудниками во время экспедиций или переданными частными лицами, школами и др. С середины 1950-х гг. сотрудниками музея была начата работа по целенаправленному и комплексному коллекционированию ювелирных изделий. Например, многие предметы вошли в музейную коллекцию благодаря этнографическим экспедициям, проводимых С. И. Вайнштейном с 1952 г. Большая часть ювелирного собрания вошла в музейный фонд в период 1969-1980-х гг. (Айжы, Бурбужеп, 2019: 194). В двух витринах-шкафах зала «Декоративноприкладное искусство Тувы. Серебро» представлено свыше 170 экспонатов, среди которых украшения, входящие в комплекс тувинского национального костюма: подвесные фигурные пряжки, огнива, ножи в ножнах. Еще представлено свыше 98 женских украшений: серьги, кольца, перстни, браслеты, гребни и два вида накосных украшений (чавага и боошкун). В основном все украшения датируются рубежом ХIX-ХХ вв.

Тувинцы независимо от пола пользовались разнообразными ювелирными изделиями, которые наделялись не только функцией украшать человека, подчеркивать его социальный статус, достаток, но и считались оберегами, защищающими от болезни и жизненных неурядиц (Вайнштейн, 1974: 94). В основном зажиточные предпочитали заказывать украшения из серебра, а люди среднего достатка довольствовались предметами из различных металлов или сплавов. Самыми распространенными мужскими украшениями являлись поясные фигурные пряжки (дергилер), огниво-кошельки (оттуктар), перстни (чүстүктер). Женские украшения отличались большим разнообразием по оформлению, технике исполнения и орнаментальной составляющей. В частности, тувинские женщины носили ювелирные изделия, которые разделялись по типам на следующие виды: украшения для прически, для ушей, рук и пальцев и для пояса. Украшения для прически - это накосные украшения чавага и боошкун; для рук и пальцев - браслеты, кольца и перстни; для пояса - поясные пряжки, огнива (Ондар, 2017: 46).

Рассмотрим украшения для прически - боошкун и чавага. По традиции боошкун считается девичьим украшением. Он особо не декорировался, так как считалось, что незамужней девушке полагалась скромность в поступках и одежде. Выйдя замуж, женщина украшала свою косу чавага, которая представляет собой пластину прямоугольной формы с заостренным или полукруглым верхом. К пластине прикрепляются более пяти нитей с бусами и шелковыми кистями черного цвета. Размер и форма данного украшения могут быть разными, однако в основном они стандартизированы. Серебряная пластинка декорируется различными орнаментами и инкрустируется полудрагоценными камнями (коралл, бирюза).

В тувинском музее представлены 4 прекрасно сохранившиеся накосные украшения чавага и 15 фрагментов пластин к ней. Все предметы сделаны из серебра, датируются, в основном, рубежом XIX-XX вв. Техника изготовления - чеканка, гравировка, инкрустация, литье. В целом работа тувинского ювелира заключалась в украшении художественной резьбой серебряной пластины.

В данном ювелирном украшении чавага (фото 1) стоит обратить внимание на орнаментальную композицию. На пластине представлен незамысловатый на первый взгляд растительный орнамент. Но если внимательно присмотреться, то мы увидим, что так называемая «цветковая» или многолепестковая розетка превращается в орнаментальный мотив «бараний рог» (кошкар мыйызы). Исследователи 
отмечают особую популярность данного орнамента в тувинской художественной обработке металла, резьбе и росписи дерева, вышивке, аппликации войлочных изделий и тиснении кожи. Так, на многих пластинах накосных украшений данный мотив «переплетается» или «прячется» за растительным узором, образуя сложную декоративную композицию. Появление данного роговидного орнамента, которого тувинцы по-другому называли кошкарлап, по мнению С. И. Вайнштейна, связано с эпохой ранних кочевников, а именно с южносибирскими племенами скифского времени (Вайнштейн, 1974: 27). Ведь во многих изделиях скифского времени изображаются головы баранов или козлов с большими рогами.
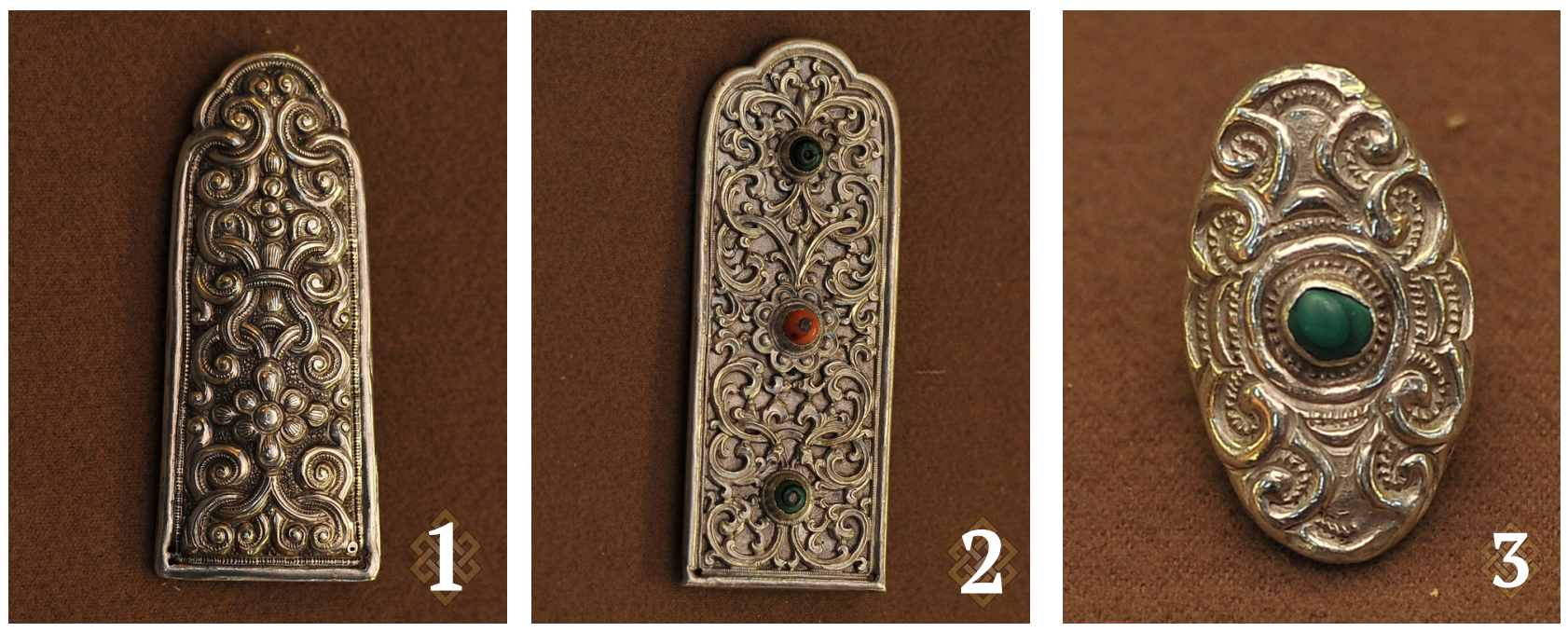

Фото 1-3: 1 - фрагмент накосного украшения, конец ХІХ в. Автор неизвестен.

Хранится в Национальном музее Республики Тыва (инвентарный номер КП 5385); 2 - фрагмент накосного украшения, начало ХХ в. Автор неизвестен. Хранится в НМ РТ (КП 7176); 3 - перстень овальной формы, конец ХІХ - начало ХХ в. Автор неизвестен. Хранится в НМ РТ (КП 9394).

Фото С. М. Еловикова, 2014 г.

Photo 1-3: 1 - fragment of a braid decoration, late 19th century, Anon. Preserved at the National Museum of the Republic of Tuva (Reg. No. KП 5385); 2 - fragment of a braid decoration, early 20th century, Anon. Preserved at the NM RT (Reg. No. KI 7176); 2 - an oval signet ring, late 19th - early 20th c., Anon. Preserved at the NM RT(Reg. No. KI 9394).

Photo by S. M. Elovikov, 2014.

На другой пластине чавага с коралловыми вставками роговидный мотив трансформировался полностью в растительные завитки (фото 2).

Роговидный орнамент также без труда узнается в женском перстне овальной формы с инкрустированным малахитом (фото 3).

Интересно, когда случилось превращение чисто зооморфного мотива в растительный? Крупный исследователь истории народов Южной Сибири С. В. Киселев, говоря об орнаментальном искусстве тюрков данного региона, отметил, что элементы орнамента скифо-сибирского стиля со временем утратили первоначальный сюжетный смысл, видоизменившись в растительные завитки (Киселев, 1951: 524). Так, наиболее вероятно, это случилось в тюркское время, и было связано с утратой предметного смысла. Об этом подробно рассуждает Т. Б. Будегечиева. Она пишет, что утрата предметного смысла предполагает трансформацию элементов анимализма в орнаментальное искусство, когда звериный мотив утрачивает первоначальный смысл и не прямо указывает на сам предмет, а стилизуется, превратившись в эстетическую категорию (Будегечиева, 1995: 46-47).

В традиционном ювелирном искусстве тувинцев в орнаментальном соотношении преобладают растительные мотивы. В частности, в женских ювелирных украшениях часто встречается один и тот же орнамент - «цветковая» или многолепестковая розетка. Например, в экспозиции представлены женские серьги с коралловыми бусами и подвеской в виде колокольчика (фото 4). 


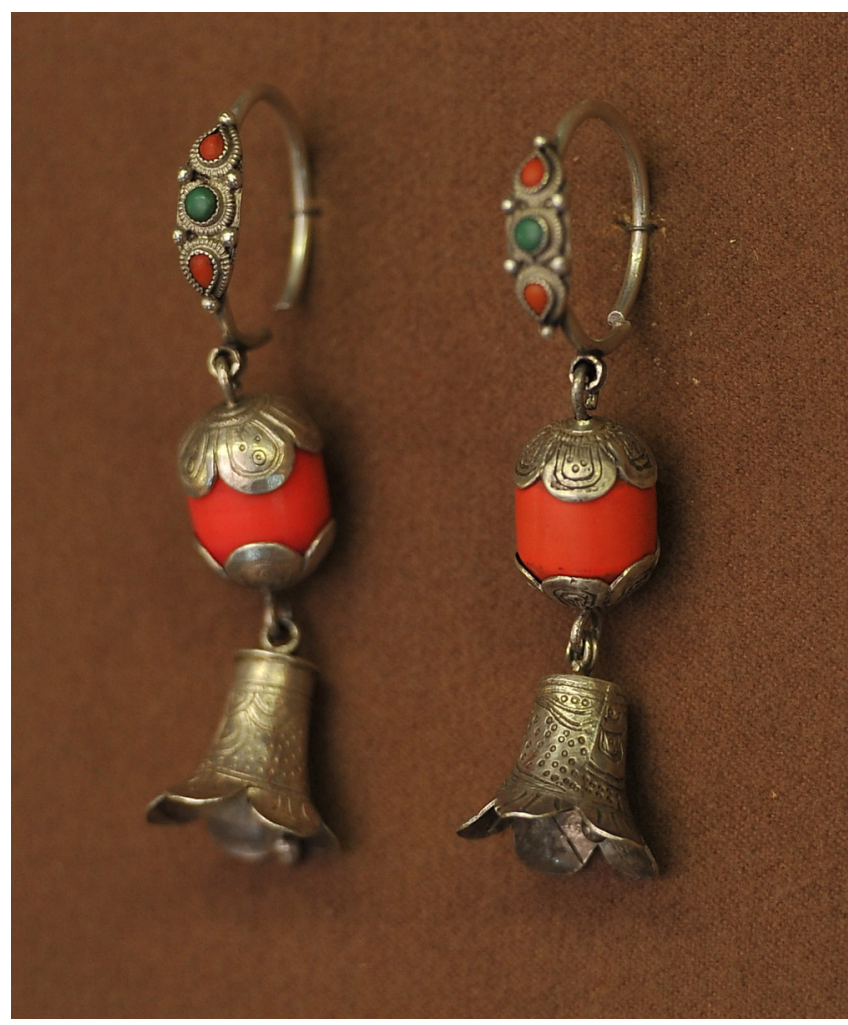

Фото 4. Серьги с подвесками в виде колокольчиков, начало ХХ в. Автор неизвестен. Хранится в Национальном музее Республики Тыва (КП 3404/1-2). Фото С. М. Еловикова, 20142.

Photo 4. Earrings with bellflower-shaped pendants, early 20th century, Anon. Preserved at the National Museum of the Republic of Tuva

(Reg. No. KП 3404/1-2). Photo by S. M. Elovikov, 2014.

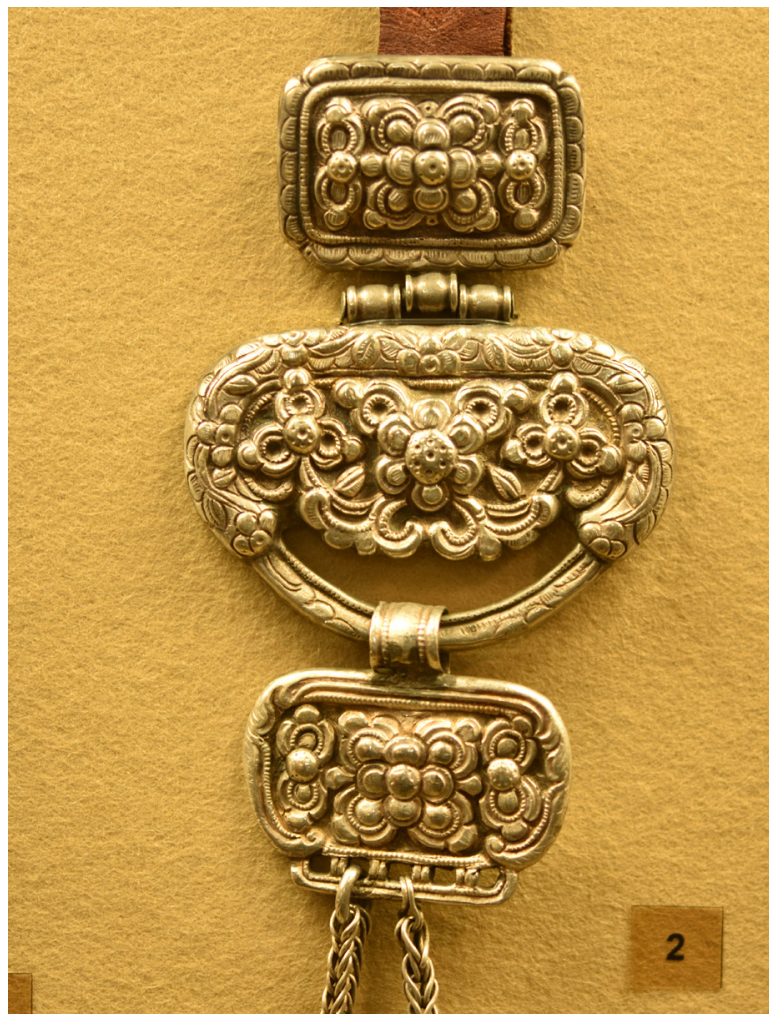

Фото 5. Женская поясная пряжка. Автор и время изготовления неизвестны. Хранится в Национальном музее Республики Тыва (КП 9274/2).

Фото А.-Д. Э. Мижита, 2021 г.

Photo 5. Female belt buckle, date unknown, Anon. Preserved at the National Museum of the Republic of Tuva

(Reg. No. KП 9274/2). Photo by A.-D. E. Mizhit, 2021.

Бусы и колокольчики сережек держатся на основании в виде пятилепесткового цветка. Такой цветок можно увидеть не только в сережках, перстнях, но и в поясных пряжках. Поясные пряжки (дергилер) один из основных элементов верхней одежды тувинцев, которые всегда были парными и имели четкое разделение на мужские и женские (Дьяконова, 1960: 155). В частности, рассмотрим женскую поясную пряжку, переданную в музейную коллекцию в 1995 г. Э. Ч. Юшаа (фото 5).

Предмет состоит из трех блях: верхней и нижней, соединенных между собой шарниром и имеющих круглую форму, средней - эллипсовидной. Поясная пряжка отличается единым художественным стилем, где основой является целостное композиционное изображение цветка и цветочных побегов.

Есть ли параллели в орнаментах племен Саяно-Алтая эпохи ранних кочевников? Интересные образцы орнаментики скифов были обнаружены недалеко от г. Ак-Довурака и с. Аксы-Барлык БарунХемчикского района, датированные, согласно книге поступлений НM PT, IX-VIII вв. до н. э. В частности, среди предметов были найдены бляхи из тонких золотых пластин в виде четырехлепестковых и пятилепестковых розеток округлой формы (фото 6-7).

Можно уловить сходство между скифской цветочной розеткой и тувинским национальным многолепестковым узором чечектеn, соответственно говорить о культурной связи.

Совершенно по-другому стоит вопрос о зооморфных мотивах и сюжетах в традиционном ювелирном искусстве тувинцев. Ведь во многих украшениях можно встретить изображения различных животных. Н. Ф. Катанов отметил в начале ХХ века следующее: «Огниво и ножи сойотского изделия в серебряной оправе были высечены изображения 12 животных, составляющий двенадцатилетний цикл счисления у монголов, маньжуров и сойотов...» (Катанов, 2011: 80). Помимо животных двенадцатилетнего цикла достаточно распространены образы мифических животных, а именно арзылана (полульва и полусобаки), демонических существ из буддийского пантеона. Например, на мужской поясной пряжке, датируе- 


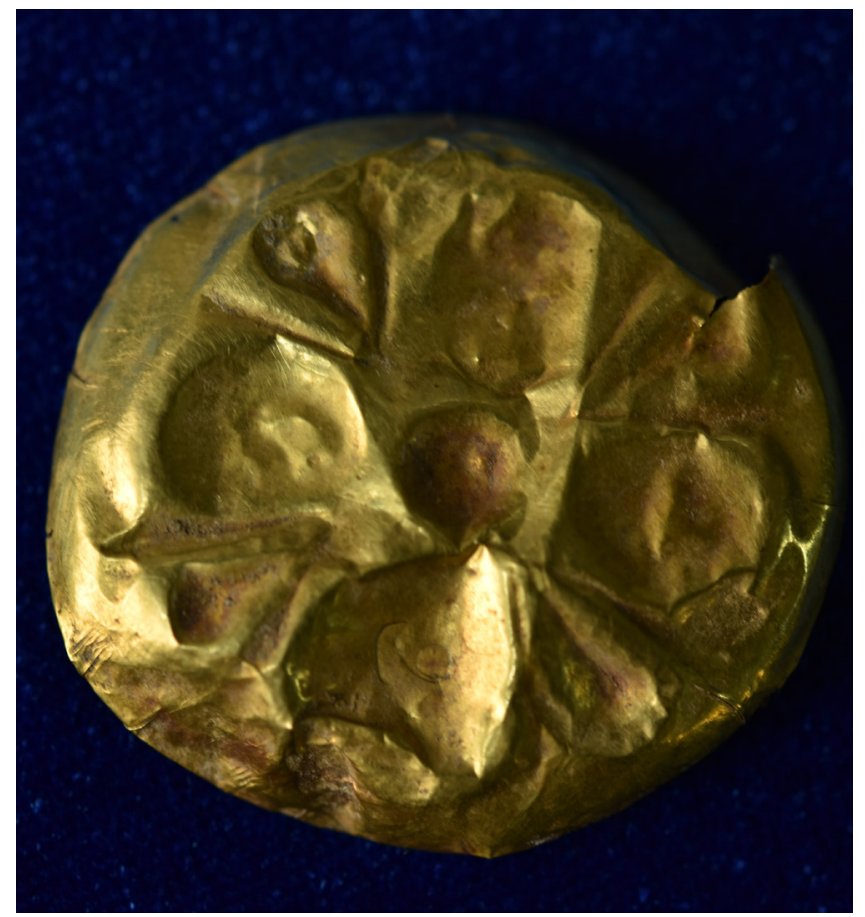

Фото 6. Нашивная бляшка в виде пятилепестковой розетки, IX-VIII вв. до н. э. Хранится в Национальном музее Республики Тыва (КП 4074). Фото А.-Д. Э. Мижита, 2021 г.

Photo 6. Sewn-on plate shaped as a five-petal rosette, 9th-8th c. BCE.

Preserved at the National Museum of the Republic of Tuva

(Reg. No. KП 4074). Photo by A.-D. E. Mizhit, 2021.

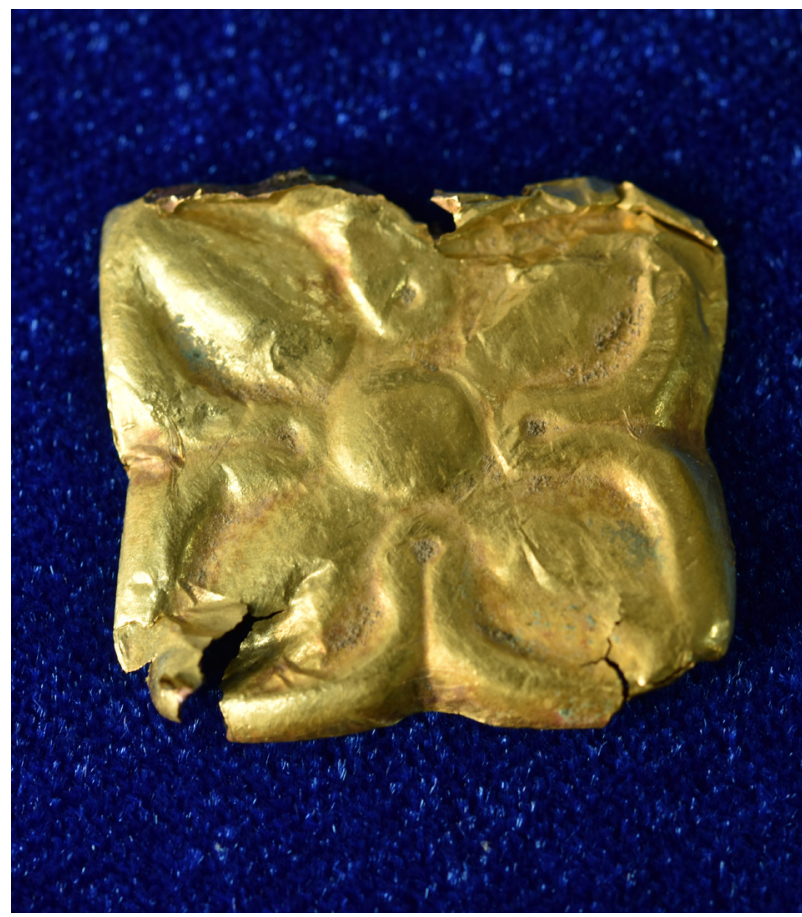

Фото 7. Нашивная бляшка в виде четырехлепесткового цзетка, IX-VIII вв. до н. э. Хранится в Национальном музее Республики Тыва (КП 4074). Фото А.-Д. Э. Мижита, 2021 г.

Photo 7. Sewn-on plate as shaped as a four-petal flower, 9th-8th c. BCE. Preserved at the National Museum of the Republic of Tuva (Reg. No. КП 4074). Photo by A.-D. E. Mizhit, 2021. мой началом XX в., представлен традиционный для тибетской мифологии демонический дух лха-дра (фото 8). Изображение его головы дублируется в центральной части верхней бляхи прямоугольной формы и в нижней овальной подвеске. Животное выглядит устрашающим с раздвинутой пастью с острым зубами, округлыми выпуклыми глазами и широким носом. Изображение лха-дры повторяется в пряжке в боковых частях нижней подвески, где он представлен в профиле. А так зооморфный образ здесь органично переплетается с растительными завитками и побегами, образуя сложную декоративную композицию. Указанный выше зооморфный образ демонического существа, как и образ арзылана являются результатом обогащения национальной тувинской культуры китайско-маньчжурско-монгольской традицией, не имеющей прямого отношения к скифо-сибирскому звериному стилю.

Краткий обзор наиболее репрезентативных украшений тувинских ювелиров XIX-XX вв. из экспозиции «Декоративно-прикладное искусство Тувы. Серебро» позволяет заключить, что в представленных ювелирных изделиях сохранились элементы скифо-сибирского звериного стиля, а именно: зооморфный орнамент кошкар мыйызы, восходящий к эпохе ранних кочевников, и растительный орнамент в виде многолепестковой цветочной розетки. Эти два мотива оказались настолько устойчивыми, что, пережив тысячелетия, они поныне бытуют в тувинском национальном искусстве, трансформировавшись и получив новое осмысление.

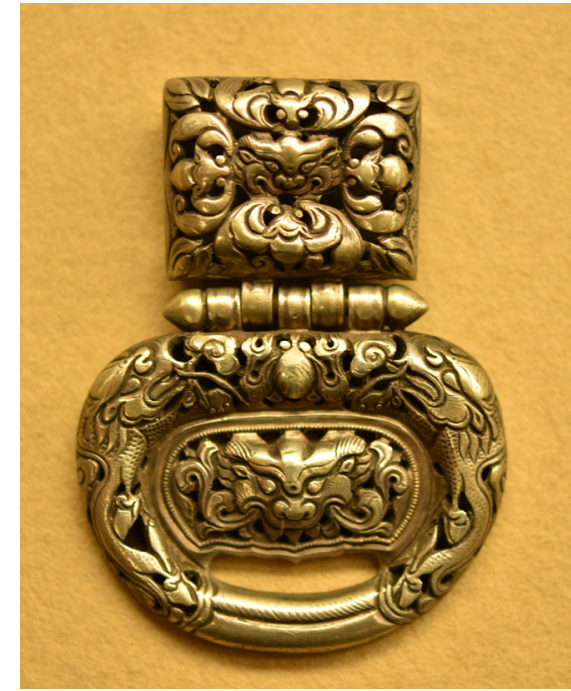

Фото 8. Мужская поясная пряжка, начало ХХ в. Автор неизвестен. Хранится в Национальном музее Республики Тыва (КП 10296/2). Фото А.-Д. Э. Мижита, 20212. Photo 8. Male belt buckle, early 20th c., Anon. Preserved at the National Museum of the Republic of Tuva (Reg. No. КП 10296/2). Photo by A.-D. E. Mizhit, 2021. 


\section{Скифское искусство и неотрадиционализм}

Скифские сюжеты и мотивы в художественной культуре Тувы стали появляться с начала 2000-х гг. в качестве одного из проявлений неотрадиционализма. Это было связано в первую очередь с открытием и функционированием экспозиции «Золото скифов: Долина царей» в Национальном музее Республики Тыва.

Если само скифское золото, составившее данную экспозицию, было найдено в 2001-2002 гг. археологами российско-германской археологической экспедиции (Чугунов, Парцингер, Наглер, 2017), то само экспонирование в Туве состоялось намного позже. Основными проблемами были: отсутствие должного здания и хранилища таких ценностей, специального оборудования и охраны. Поэтому, правительство Тувы закончило строительство головного здания музея, который до этого строился 17 лет. 7 февраля 2008 г. здание в г. Кызыле по ул. Титова, д. 30 было открыто, а 2 ноября 2008 г. жители и гости республики впервые увидели воочию шедевры скифского искусства.

Тувинские деятели искусства, ознакомившись воочию с произведениями скифских мастеров и ювелиров, стали активно использовать сюжеты, мотивы, образы древности. Знаковые предметы, обнаруженные в курганах Аржан и Аржан-2, стали использоваться для создания логотипов государственных научно-исследовательских и образовательно-просветительских учреждений. Так, символом Тувинского института гуманитарных и прикладных социально-экономических исследований при Правительстве Республики Тыва стала бронзовая бляха в виде свернувшейся пантеры, которая считается одним из самых ранних образцов скифского звериного стиля (фото 9). Навершие шпильки в виде фигурки оленя царицы из кургана Аржан-2 вошло в логотип Национального музея Республики Тыва (фото 10).

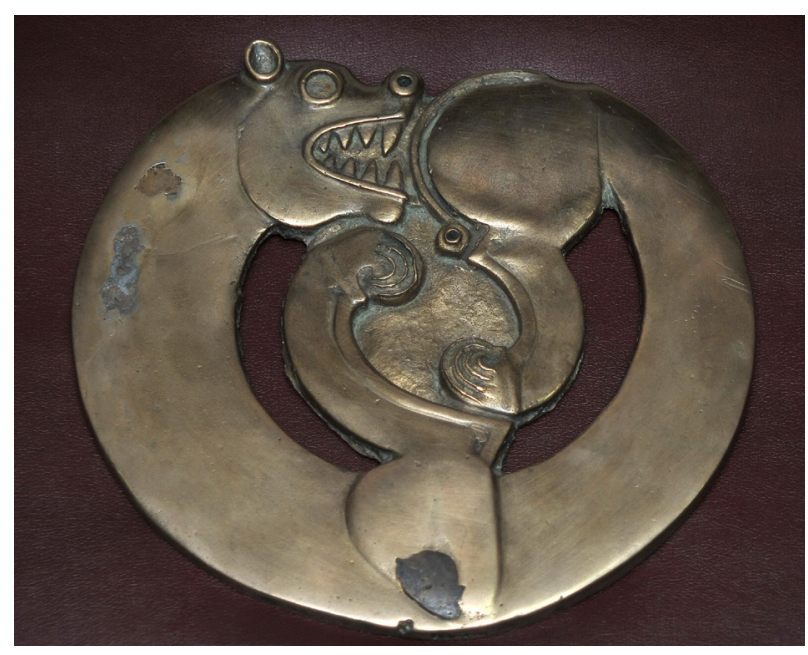

Фото 9. Бронзовая бляха в виде свернувшейся пантеры из кургана Аржан, IX-VIII в. до н. э. Хранится

в Национальном музее Республики Тыва (КП 5479/41). Фото А. Д. Куулар, 2020 г.

Photo 9. Bronze plate shaped as a coiled pattern from Arzhan mound, 9th-8th c. BC. Preserved at the National Museum of the Republic of Tuva (Reg. No. KП 5479/41).

Photo by A. D. Kuular, 2020.

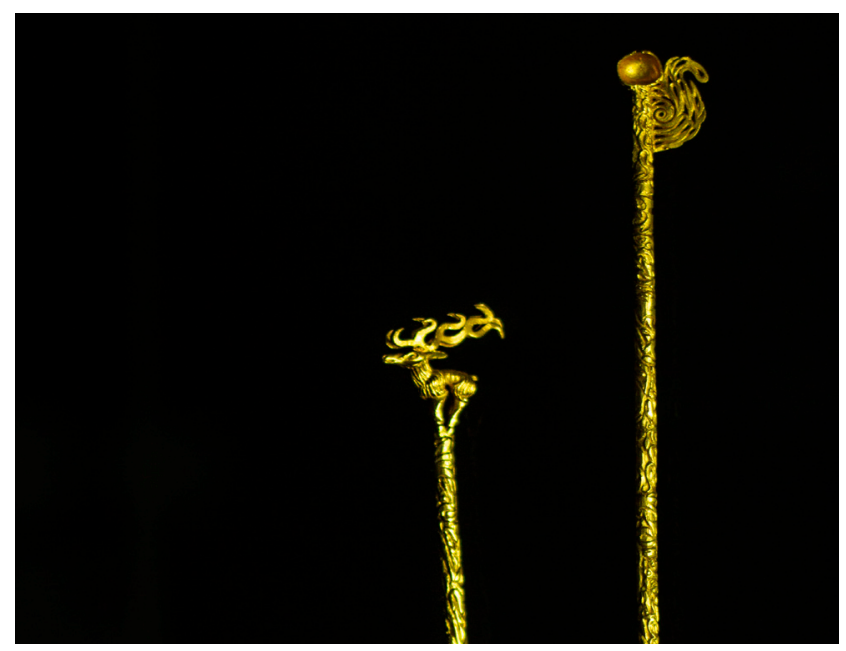

Фото 10. Шпилька в виде фигурки оленя из кургана Аржан-2, вторая половина VII в. до н. э. Хранится

в Национальном музее Республики Тыва (КП 11195/513). Фото А.-Д. Э. Мижита, 2021 г.

Photo 10. A deer-shaped hairpin from Arhzhan II mound, latter half of 7 th c. BC. Preserved at the National Museum of the Republic of Tuva (Reg. No. KП 11195/513). Photo by A.-D. E. Mizhit, 2021.

К искусству древних скифов обратились также тувинские ювелиры, увидевшие в скифо-сибирском зверином стиле новые возможности для развития и обогащения своего художественного языка. Ювелирное искусство Тувы, в отличие от камнерезного искусства, развивавшего планомерно по всем направлениям и жанрам, где всегда было место экспериментам, поиску новых форм и художественного языка, развивалось в русле традиционных форм. И в этом оно также отличалось от ситуации в Якутии и Бурятии, где ювелирное искусство заняло одно из главенствующих позиций в декоративно-прикладном искусстве и с развитием традиций, и с ориентацией на современные тренды и направления (Петрова, Соловьева, 2017: 29). В частности, в Якутии уже работает целая плеяда дизайнеров-ювелиров по созданию оригинальных украшений, представляющих неповторимый стиль этномодерна (Бравина, Иванова-Унарова, 2020: 61). При этом в Якутии ювелирное дело ориентировано на изготовление 
серебряных украшений. Развитие данного направления строится на деятельности крупных частных фирм «Уран Саха», «Киэргэ», «Симэх», «Саха дизайн» и др. (Москвина, Павлова, 2015: 288).

Что касается ювелирного дела в Туве, то здесь сегодня работают мастера в рамках «традиционной» ювелирной школы, которые черпают идеи в национальных орнаментах и богатой символике буддизма. К этим мастерам-ювелирам можно отнести Кенина Сата (г. Кызыл), Владимира Салчака (с. Кызыл-Даг), Байбека Борбака (г. Шагонар), Николая Самдана (г. Кызыл), Юрия Тойбухаа (г. Кызыл). И появились ювелиры - Венера Никулина (г. Кызыл), Айбес Олчей (г. Кызыл), Елена Седип (г. Кызыл), - выбравшие свои подходы к представлению «скифо-сибирского звериного стиля» в своих произведениях. Надо сказать, что Венера Никулина и Айбес Олчей также достаточно плодотворно работают в традиционной технике, изготавливая национальные тувинские украшения. Их обращение к скифским сюжетам и мотивам характеризуется стремлением не только выйти за рамки традиций, заложенных национальной культурой, но и желанием авторской импровизации. В уникальной технике работает мастер Елена Седип, которая в Туве развивает редкое направление бисероплетения с использованием драгоценных и полудрагоценных камней.

\section{Венера Никулина: функциональный скифо-сибирский звериный стиль}

В Кызылском колледже искусств им. А. Б. Чыргал-оола художественную обработку металла преподает ювелир Венера Копеековна Никулина, занимающаяся данным искусством на протяжении двенадцати лет.

Путь в ювелирное дело В. К. Никулиной был тернистым. Родилась 20 февраля 1974 г. в с. Аксы-Барлык Барун-Хемчикского района Тувинской АССР. Как и все молодые люди перепробовала себя во многих сферах, прежде чем найти себя в ювелирной стезе. После окончания средней образовательной школы поступила в сельскохозяйственный институт Тувинского государственного университета. Проучившись там два года, решила полностью сменить сферу деятельности. Поступила в Торжокское золотошвейное училище в Тверской области, где издавна существовала сильная школа по художественной вышивке в России. Успешно закончив данное учебное заведение, вернулась обратно в Туву, в родное село Аксы-Барлык, где стала учителем труда в местной школе. Чувствуя необходимость в дальнейшем обучении, поступила в Хакасский государственный университет им. Н. Ф. Катанова на специальность «Декоративно-прикладное искусство и народные промыслы». Именно здесь она освоила основы художественной обработки металла. Проучившись в Абакане, Венера Никулина решила более серьезно освоить ювелирное дело. Так, она поступила в Красносельское училище художественной обработки металлов, где уже на протяжении ста лет готовят специалистов по ювелирному делу для крупных ювелирных заводов и частных компаний. После окончания училища для закрепления теоретических и практических навыков, осталась работать в мастерской данного учебного заведения, где на протяжении года оттачивала свое мастерство в ювелирном деле. Так, молодой ювелир обратно вернулась на родину и сразу занялась преподавательской деятельностью в Детской школе искусств г. Ак-Довурака, где вела кружок по художественной вышивке.

С 2014 г. В. К. Никулина преподает в Кызылском колледже искусств, в котором открылась ювелирная мастерская и где она занялась обучением будущих ювелиров. В 2019 г. выпустила первый набор (6 учащихся) по направлению «Декоративно-прикладное искусство и народные промыслы (по виду): Художественный металл». Это стало важным событием для современной художественной культуры Тувы, поскольку республика впервые получила ювелиров, получивших профильное образование, и которые, возможно, будут развивать тувинское ювелирное искусство.

Что касается индивидуального творчества, то В. К. Никулина начала изготавливать авторские ювелирные изделия с 2008 г. Сначала она работала в рамках традиционного тувинского ювелирного искусства, скрупулезно изучив семантику всего разнообразия тувинской орнаментики. Как и мастера прошлого, она создает серебряные украшения с инкрустацией кораллами, нефритом, бирюзой. При этом ювелир активно внедряет другие камни, добавляя жемчуг, фианит, яшму и др. Она прекрасно владеет гравировкой, штамповкой, насечкой, филигранью.

Совершенно новой линией в ее творческой деятельности стал скифо-сибирский звериный стиль. Впервые она увидела лучшие образцы ювелирного искусства скифов в Национальном музее Республики Тыва в 2008 г. и с тех пор неоднократно посещала «Золотой зал», как нередко называют экспозицию скифского золота. Так, она загорелась желанием создать ювелирные украшения с использованием основных скифских образов. 


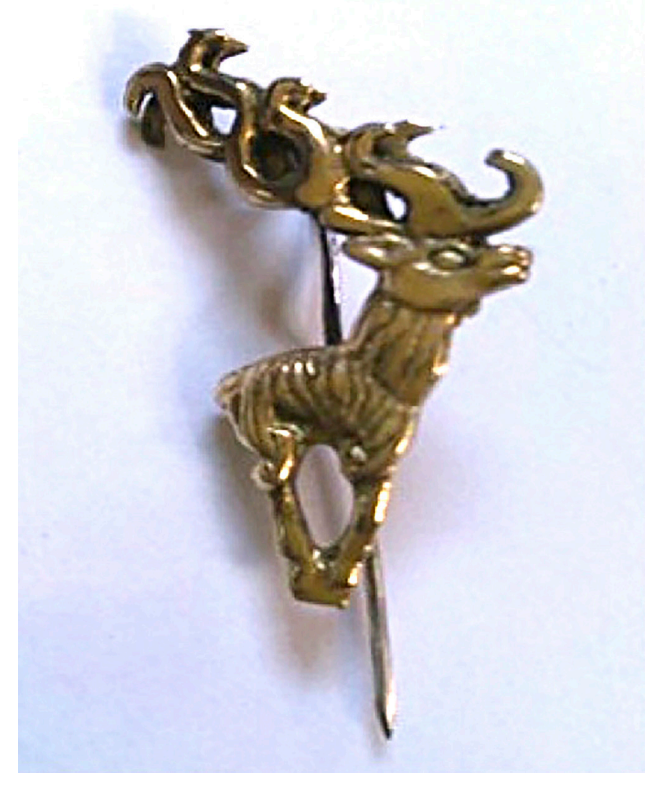

Фото 11. Фибула «Скифский олень» Венеры Никулиной. Фото из архива В. К. Никулиной, 2010

Photo 11. The 'Scythian deer' fibula,

by Venera Nikulina. Courtesy of V. K. Nikulina's personal photo archive, 2010.

Ключевой идеей в ювелирной концепции мастера является тезис «чистоты» звериного стиля. Прекрасно владея тонкостями и техниками не только тувинской художественной обработки металла, но и традициями тверской ювелирной школы, Венера Никулина могла бы сочетать совершенно две разные направления в своем творчестве, комбинируя их еще со звериным стилем. Однако ювелир четко придерживается минималистического взгляда на древнее искусство кочевников. В своем интервью одному из соавторов данной статьи в октябре 2020 г. она подчеркивала цельность и емкость скифо-сибирского звериного стиля, не требующего добавления никаких других орнаментальных мотивов и вставок драгоценных или полудрагоценных камней ${ }^{1}$. Поэтому работы мастера отличаются простотой композиционного построения, строгостью форм.

Например, изготовленная по заказу частному лицу фибула ${ }^{2}$ «Скифский олень», вдохновленная навершием шпильки царицы (фото 11).

На первый взгляд, украшение повторяет работу древнего ювелира, воссоздавшего образ благородного оленя. Однако в художественном построении образа животного можно отметить две отличающиеся детали. Во-первых, современный ювелир, в отличие от скифского мастера, не зависит от канонов данного стиля. Как пишут многие исследователи, в парадигме кочевников евразийских степей Вселенная строго разделялась по вертикали на три мира: верхний (небесный), средний (принадлежащий людям) и нижний (подземный) (напр.: Переводчикова, 1994: 13). Скифский ювелир в оформлении различных предметов вкладывал представления о картине мира, поскольку и вещь, и изображение на ней были связаны с общей идеей о строении мироздания. Поэтому олень для скифов был небесным животным, и он мог быть украшением предметов, находящихся на уровне головы (Грязнов, 1978: 232). Так, данная шпилька украшала высокую

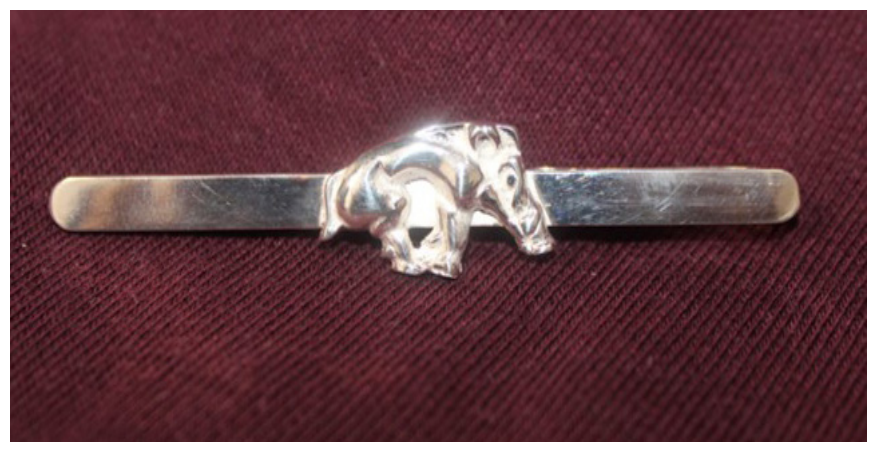

Фото 12. Зажим в виде фигурок кабанов Венеры Никулиной. Фото из архива В. К. Никулиной, 2010 г.

Photo 12. A clamp shaped as boar figurines, by Venera Nikulina. Courtesy of V. K. Nikulina's personal photo archive, 2010.

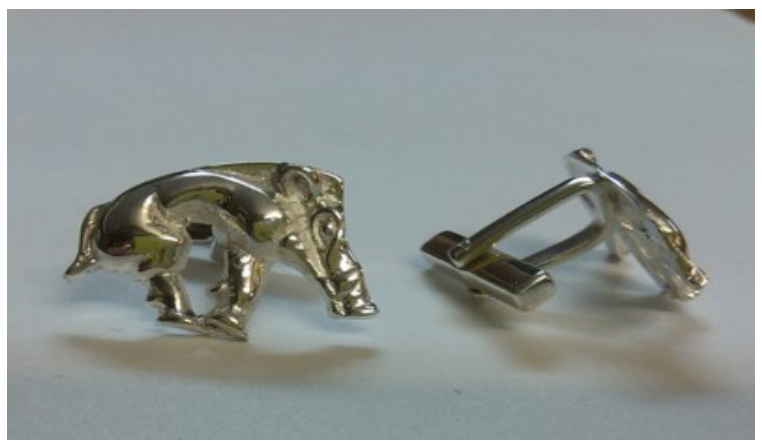

Фото 13. Запонки в виде фигурок кабанов Венеры Никулиной. Фото из архива В. К. Никулиной, 2010 г.

Photo 13. Cuff-links shaped as boar figurines, by Venera Nikulina. Courtesy of V.K. Nikulina's personal photo archive.

прическу и головной убор скифской царицы (Чугунов, Парцингер, Наглер, 2004: 12). Для В. К. Никулиной, как и для современного заказчика, соблюдение основных канонических постулатов звериного стиля не важно. Фигурку благородного оленя с ветвистыми рогами ювелир представила как фибулу -

\footnotetext{
${ }^{1}$ Интервью с Венерой Никулиной (на тув. языке) Ж. Э. Айжы. Записано в г. Кызыл 30.10.2020 г.

${ }^{2}$ Фибула - металлическая застежка для одежды, служащая также украшением.
} 
брошь или зажим для одежды, т. е. как предмет с определенной функциональностью. То же самое видно по зажиму для галстука и запонкам в виде фигурки кабана (фото 12-13).

В качестве образца ювелир использует бляшки в виде фигур кабанов, украшавших горит или налучье с колчаном царя из кургана Аржан-2. Как отмечает А. Ю. Алексеев, изображение кабана на предметах вооружения не случайно, так как в бестиарии звериного стиля он был символом мужской храбрости и доблести (Алексеев, 2012: 56). Е. В. Переводчикова дополняет мысль об амбивалентности образа вепря: «Поскольку его природа виделась двойственной: с одной стороны, это копытное животное, с другой же - плотоядный зверь, в этом смысле родственный хищникам» (Переводчикова, 1994: 46). Современный ювелир также соотносит образа кабана с мужским началом, создавая строгие в своем минимализме украшения из серебра. Тем не менее, ее украшения актуальны под любой стиль независимо от возраста, пола и индивидуальных особенностей. Если ювелирные украшения из курганов Аржан и Аржан-2, возможно, были специально изготовлены для погребальной церемонии для элиты скифского общества, то изделия Венеры Никулиной прекрасно сочетаются с повседневной одеждой благодаря лаконизму и строгости линий.

Таким образом, скифо-сибирские образы в ювелирных украшениях тувинского педагога и ювелира Венеры Никулиной представлены в виде основных животных-символов - оленя и кабана - и выражены в минималистическом стиле с функциональным акцентом.

\section{Айбес Олчей: созвучие национальных ювелирных традиций Тувы и Якутии в скифо-сибирском зверином стиле}

Совершенно в другом направлении работает молодой ювелир Айбес Сергеевич Олчей, известный в Туве и за ее пределами не только как ювелир, камнерез, но и мастер по изготовлению конского снаряжения. В 2017 г. в рамках празднования национального праздника Наадым в межрегиональном конкурсе «Наследие предков» он стал победителем - мастером, изготовившим лучшее конское убранство ${ }^{1}$.

А. С. Олчей родился 14 июня 1979 г. в селе Барлык Барун-Хемчикского района в семье художника. Его творческое становление началось, как у многих тувинских мастеров, с камнерезного искусства. В Кызыл-Мажалыкской детской школе искусств под руководством опытного камнереза, художника Майны Биче-оола он начал делать поделки из агальматолита. После окончания школы выбрал профессию столяра-резчика в Профессиональном училище № 4 г. Кызыла, где он освоил резьбу по дереву. При этом не забросил камнерезное искусство, постоянно оттачивая свою технику. Высшее образование получил в Тувинском государственном университете на инженерно-техническом факультете. Поворотным пунктом в карьере мастера стала стажировка в г. Якутске, где он решил освоить ювелирное дело. В 2008 г. он поступил подмастерьем в известную частную ювелирную фирму «Киэргэ», где занимался частными заказами. За два года он освоил основные современные техники по художественной обработке металла и познакомился с традиционным и современным ювелирным искусством якутов.

В 2010 г. А. С. Олчей вернулся в Туву, где в Кызыле он открыл свою мастерскую и приступил к изготовлению авторских ювелирных изделий, которые стали востребованы. Работы ювелира, по нашему мнению, узнаваемы благодаря трем ключевым аспектам. Во-первых, филигранностью художественной техники - все изделия отличаются утонченной ажурностью и тщательной проработкой деталей. Вовторых, сочетанием различных материалов: кости, металла, полудрагоценных камней. В-третьих, смелым совмещением различных ювелирных традиций и стилей, что является самой главной отличительной чертой художественного языка ювелира. Все три аспекта можно увидеть не только в ювелирных изделиях мастера, но и в его камнерезных работах.

В Национальном музее Тувы в экспозиции «Декоративно-прикладное искусство. Серебро» представлена шпилька с навершием в виде фигурки оленя, вдохновленная аналогичным золотым украшением скифской царицы из кургана Аржан-2 (фото 14). Ювелир в качестве основных материалов использует серебро, кость и полудрагоценный камень гранат. Стержень изделия выполнена из гладкой

\footnotetext{
${ }^{1}$ Первое место в конкурсе на лучшее конское снаряжение - у Айбеса Олчея (Тува) [Электронный ресурс] // ИА Туваонлайн. 2017, 18 августа. URL: https://www.tuvaonline.ru/2017/08/18/pervoe-mesto-v-konkurse-na-luchsheekonskoe-snaryazhenie-u-aybesa-olcheya-tuva.html (дата обращения: 06.11.2020).
} 


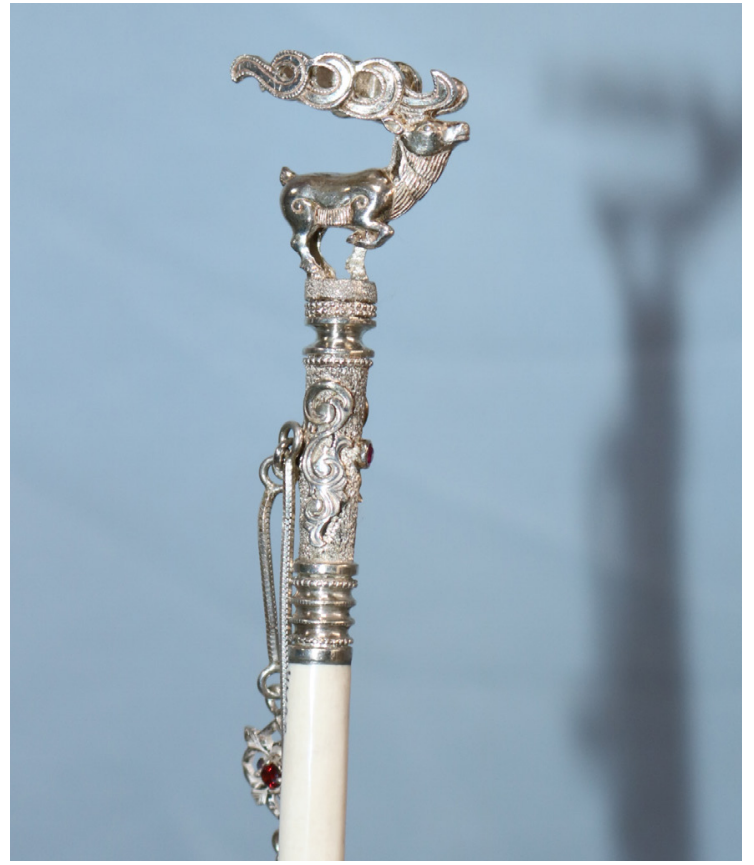

Фото 14. Шпилька с навершием в виде оленя.

Автор Айбес Олчей, 2016 г. Хранится в Национальном музее Республики Тыва.

Фото С. Л. Бырыннай, 2020 2.

Photo 14. A hairpin with its top shaped as a deer, by Aibes Olchei, 2016. Preserved at the National Museum of the Republic of Tuva. Photo by S. L. Byrynnai, 2020. отшлифованной кости, навершие с фигуркой оленя и подвеска - из серебра. Автором ювелирное украшение продумано не как копия скифской шпильки, а, скорее, как отсылка к ней, так как есть отличительные моменты.

Анализ стоит начать с образа оленя, где сразу видно, что олень выполнен не по скифскому канону. М. П. Грязнов выделил для саяно-алтайского оленя характерную стоящую позу, как бы «на цыпочках» с прямыми ногами (Грязнов, 1978: 226). К. В. Чугунов применительно к образу оленя из кургана Аржан-2 упоминает об «аржано-майэмирском стиле», где типичны изображения оленей с прямыми ногами (Chugunov, 2017: 74). У А. Олчея олень тоже изображен стоящим с прямыми ногами, но с подогнутой передней конечностью. Возможно, данный образ, скорее всего, относится к иконографии камнерезного искусства Тувы, закрепленной многолетней традицией. Именно в анималистическом жанре скульптуры малых форм можно увидеть такую характерную позу диких животных в работах Монгуша Черзи и Хертека Тойбухаа, родоначальников камнерезного искусства Тувы. Принадлежность данного оленя к тувинской камнерезной пластике доказывается еще сочетанием реалистической трактовки и декоративной стилизации, своеобразной характеристикой тувинской пластики малых форм (Иргит, 2017: 43). Ведь ювелир стилизовал шерсть оленя вертикальной прорезкой, что часто

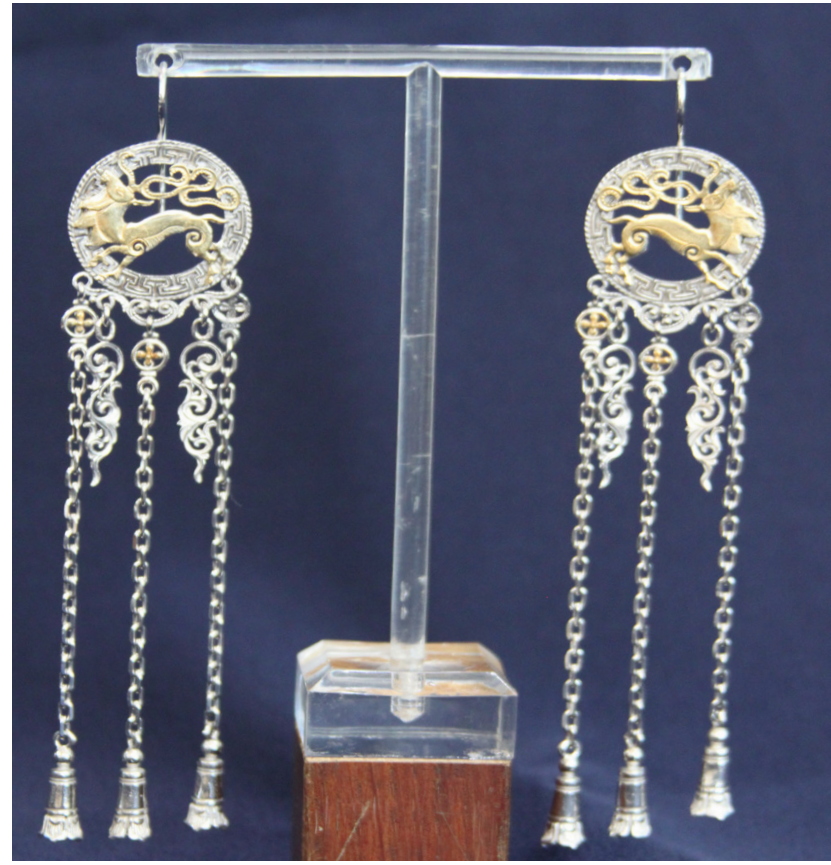

Фото 15. Серьги с тремя цеепочными подвескам и фигуркой оленя. Автор А. С. Олчей, 2019 г. Фото А. С. Хертека.

Photo 15. Earrings with three chain pendants and a deer figurine, by A. S. Olchei, 2019. Photo by A. S. Khertek.

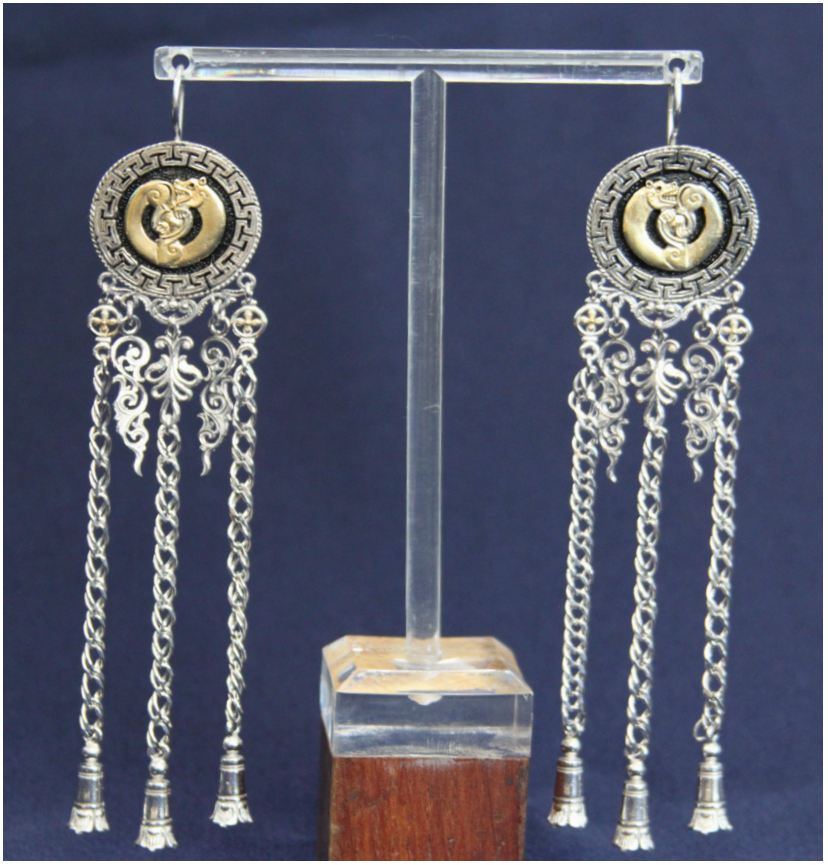

Фото 16. Серьги с тремя цеепочными подвесками и фигуркой свернувшейся пантеры. Автор А. С. Олчей, 2019 г. Фото А. С. Хертека.

Photo 16. Earrings with three chain pendants and a coiled-up panther figurine, by A.S. Olchei, 2019. Photo by A. S. Khertek. 
встречается в камнерезных работах, при этом, не забыв ветвистые рога животного представить в традициях скифского искусства.

Такое смелое сочетание традиций камнерезного искусства и приемов скифо-сибирского звериного стиля - не последнее в авторской задумке. Далее комбинирование металла и кости отсылает к традициям якутского народного искусства, где существует сильная косторезная школа. В Туве резьба по кости в целом представлена тоже в скульптуре малых форм, где мастера делали небольшие фигурки людей и животных, а в традиционном ювелирном искусстве тувинцев кость не является распространенным материалом.

Помимо влияния якутского ювелирного искусства в творчестве А. Олчея хорошо прослеживаются традиции тувинского ювелирного дела, которые прекрасно отражены в двух комплектах сережек работы мастера (фото 15-16). Украшения по своей форме напоминают традиционные женские сережки с цепочками с ко-

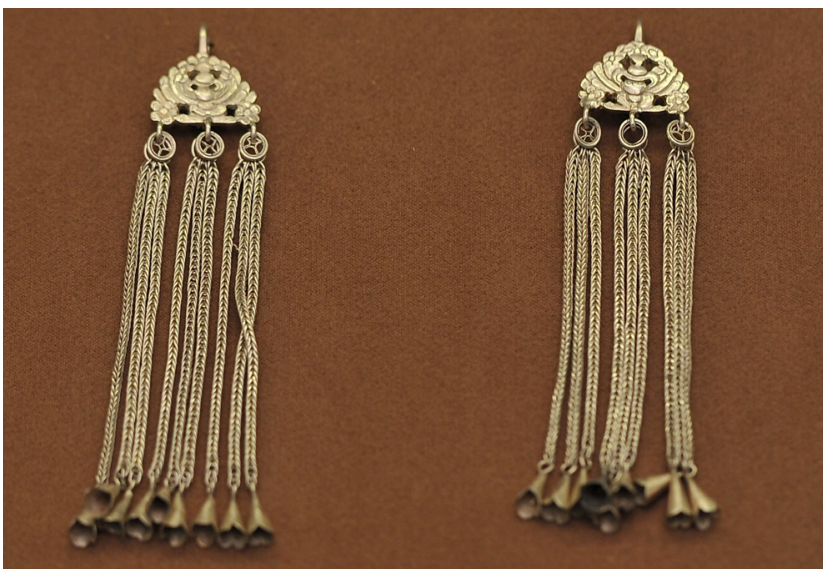

Фото 17. Серьги с 9-целочными подвесками.

Автор неизвестен, начало ХХ в. Хранится в Национальном музее РТ (КП 3403/1-2). Фото С. М. Еловикова, 20142.

Photo 17. Earrings with nine chain pendants Anon, early 20th c. Preserved at the National Museum of the Republic of Tuva (Reg. No 3403/1-2). Photo by S. M. Elovikov, 2014. локольчиками на концах.

Такого вида серьги, датированные началом XX в., широко представлены в экспозиции тувинского музея (фото 17).

В отличие от традиционных тувинских сережек, украшенных буддийскими символами или зооморфными, растительными орнаментами, в данных изделиях (фото 15 и 16) ключевое место занимают основные образы скифо-сибирского звериного стиля - олень и свернувшаяся в круг пантера. Оформленные в круглом диске и обрамленные меандрическим орнаментом скифские животные как бы «заключены» в пространство этого диска, ограничены в свободе. При этом олень, изображенный в «летучем галопе» в одной паре серег (фото 15) пытается освободиться из пространства диска - его копыто «выходит» за рамки диска. Три цепочки с колокольчиками и двумя подвесками скрепляются в серьгах с диском с помощью ажурной пряжки. И две подвески с пряжкой типичны по орнаментальной композиции с якутскими ювелирными традициями, где в серьгах часто встречаются мотивы в виде тоненьких веточек и вьющихся стеблей (Хабарова, 1981: 26). Также способ декорировки украшений преимущественно гравировкой и ажурной резьбой тоже восходит к якутской традиции.

Таким образом, в творчестве мастера Айбеса Олчея скифские сюжеты и мотивы представлены в связи с тувинскими и якутскими ювелирными традициями.

\section{Елена Седип: скифские сюжеты и мотивы в бисероплетении}

Совершенно в другом направлении работает тувинский мастер Елена Владимировна Седип, занимающаяся на протяжении двадцати пяти лет изготовлением ювелирных украшений и аксессуаров из бисера.

Е. В. Седип родилась в 1968 г. в городе Киселевске Кемеровской области. В 1972 г. вместе с семьей переехала в город Кызыл. После окончания средней школы № 11 поступила в автодорожный техникум.

Впервые плетением бисером занялась в 1989 г. Это было связано с возрождением данного вида декоративно-прикладного искусства в России, когда повсеместно возникли мастерские, объединения, кружки, школы бисероплетения (Замега, 2015: 196). Интерес к бисеру привел Е. В. Седип к преподавательской деятельности - с 1995 г. она начала обучать школьников плетению по бисеру в Центре дополнительного образования в Кызыле. В последнее время преподает плетение по бисеру в средней школе № $7^{1}$.

${ }^{1}$ Информация об авторе [Электронный ресурс] // Сайт Елены Седип. URL: http://elena.sedip.ru/index.php/page/150 (дата обращения: 11.10 .2020$)$ 
С начала 2000-х гг. Е. В. Седип стала активно участвовать в республиканских, межрегиональных, всероссийских и международных выставках. Участие в выставках всероссийского и регионального уровней в рамках конкурсов «100 лучших товаров России», «Лучший товар Тувы», «Регионы России» позволили автору продемонстрировать свое творчество в ракурсе современного развития тувинского декоративно-прикладного искусства.

Интерес к бисероплетению, как особенному направлению в ювелирном искусстве Тувы, Е. Седип представила на персональной выставке «Искусство красоты», прошедшей в Национальном музее PT 4-8 марта $2020 \Gamma^{1}$. Авторы статьи занимались организацией данной выставки и непосредственно знакомились с приемами и оригинальными техниками плетения бисера. На выставке были представлены гайтаны ${ }^{2}$, колье, броши, браслеты, подвески и др. Посетители выставки больше всего приметили традиционное русское нашейное украшение гайтан, украшенный тувинским национальным орнаментом «узлом счастья» (олчей удазыны). Каждый человек, посетивший выставку, отметил не только своеобразие каждого украшения, но и как совершенно по-новому смотрятся национальные тувинские орнаменты и узоры на таком материале как бисер.

Среди украшений автора особо стоит выделить колье, в которых из многочисленных бисеринок проявляются образы животных из скифского бестиария. Колье представляют собой круглые обручи шириной 4 см, от центральной части которых опускаются многочисленные нити с бисеринками, где на контрасте черных, служащих фоном, и золотистых бисеринок, отражаются скифские животные. Мастером выбраны бисеринки качественного чешского производства, которые отличаются легкостью, изяществом и блеском. В первом ювелирном изделии представлен олень из навершия шпильки царицы, а во втором - свернувшаяся пантера из кургана Аржан (фото 18 и 19).
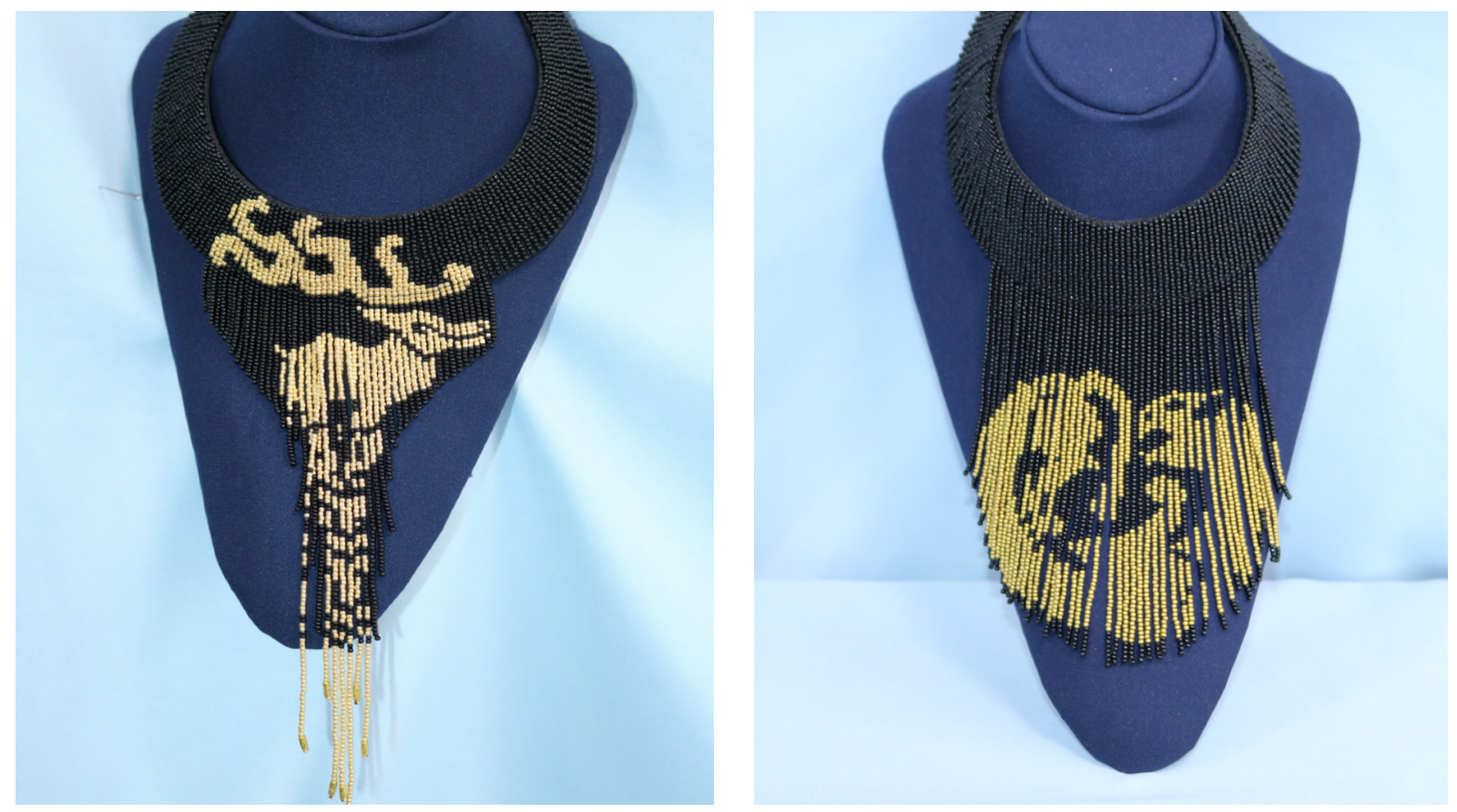

Фото 18 и 19. Колье из бисера «Скифский олень» и «Скифская пантера». Автор Елена Седип, 2020 г. Фото Ж. Э. Айжы, 2020 г. Photo 18-19. "Scythian deer" and "Scythian panther" bead necklace, by Yelena Sedip, 2019. Photo by Zh. E. Ayzhy, 2020.

\footnotetext{
${ }^{1}$ Открытие персональной выставки мастера декоративно-прикладного творчества - Елены Седип [Электронный ресурс] // Национальный музей Республики Тыва. URL: http://museum.tuva.ru/?p=8676 (дата обращения: 11.10.2020).

${ }^{2}$ Нагрудное украшение в виде кольца из тканой или ажурной ленты из бисера разной ширины и длины с концами, соединенными в медальон. Такое украшение надевалось на шею и спускалось по груди иногда до талии. Женщины в праздничный день надевали, как правило, несколько таких украшений (Неслуховская, 2016: 67).
} 
Олень, как мы уже упоминали, является одним из основных образов в скифо-сибирском зверином стиле. В ювелирном украшении Елены Седип олень представлен в каноническом образе - стоящим на цыпочках, в профиль и с ветвистыми изогнутыми рогами. При этом стоит подчеркнуть следующую особенность, связанную с ногами оленя. В данном изделии они выполнены не канонически - они соединены воедино, при этом бисер как бы «растворяет» их, что символично, и перекликается с небесным происхождением скифского оленя.

Изображение свернувшегося в кольцо хищника является одним из главных сюжетных линий в зверином искусстве. Во втором колье ювелир представила образ свернувшейся в кольцо пантеры из бронзовой бляхи, обнаруженной в камере № 2, примыкающей к центральной царской камере, кургана Аржан. Данный предмет является одним из знаковых археологических находок в истории Тувы. Исследователь археологического комплекса Аржан М. П. Грязнов предполагает, что возможно данная бляха является нагрудным украшением царского коня, сакральные смыслы которого связаны с конской упряжью (Грязнов, 1980: 50). Согласно иконографической основе, образ зверя отличается компактностью, композиционной замкнутостью и принципом «ухо, глаз, ноздря на одной линии» (Канторович, 2014: 71). Современный ювелир также постаралась через контраст черного бисера, служащего фоном, и золотых бисер, изображающих пантеру, создать гармоничную в своей статичности композицию. Конечно, в бисере сложно представить полностью анатомические детали изображенного хищника. Однако ювелир, вдохновившись бляхой, представила свой вариант образа пантеры, при этом сохранив композиционное построение оригинального артефакта.

Таким образом, на примере двух нагрудных украшений из бисера Елена Седип представила свою интерпретацию образов звериного стиля.

\section{Заключение}

Как показало наше исследование, в традиционном ювелирном искусстве Тувы конца XIX - начала XX в., преемственность с искусством эпохи ранних кочевников прослеживается мало. Сохранились трансформированный под растительный узор зооморфный орнамент кошкар мыйызы и растительный мотив чечектеп в виде многолепестковой цветочной розетки, берущие свои истоки в искусстве древних скифов.

Скифо-сибирский стиль стал специально возрождаться в современном ювелирном искусстве Тувы с 2000-х гг. и это было связано с открытием в Национальном музее Тувы постоянной экспозиции, что позволило ювелирам, также как и другим посетителям, ознакомиться с украшениями царской четы и знати из курганов Аржан и Аржан-2. Мы показали разные подходы и интерпретации скифских сюжетов и мотивов в ювелирном творчестве на примере работ трех современных мастеров Тувы Венеры Никулиной, Айбеса Олчея и Елены Седип. Анализ их ювелирных украшений позволяет говорить о формировании нового направления в современном ювелирном искусстве Тувы, в котором по-новому осмысливаются древние образы и мотивы. И в данном направлении основные персонажи скифского бестиария - олень, пантера, кабан - могут быть гармонично трансформированы не только под современные трендовые ювелирные украшения и аксессуары, но и интерпретированы, исходя из эстетических канонов ювелирного искусства тувинцев, а также опираясь на опыт других региональных школ и направлений.

\section{СПИСОК ЛИТЕРАТУРЫ}

Айжы, Ж. Э., Бурбужеп, Д. Д. (2019) К вопросу представления ювелирного искусства в Национальном музее Республики Тыва // Ермолаевские чтения: материалы III научно-практической конференции с международным участием (23-25 мая 2019 г.), посвященной 90-летию со дня основания Национального музея им. Алдан-Маадыр Республики Тыва / отв. ред. А. К. Тамдын. Кызыл : Типография МБОУ КЦО «Аныяк». 256 с. С. 193-197.

Алексеев, А. Ю. (2012) Золото скифских царей в собрании Эрмитажа. СПб. : Изд-во Гос. Эрмитажа. 272 с.

Бравина, Р. И., Иванова-Унарова, 3. И. (2020) Сияние серебра: традиционные украшения якутов. От истоков к современности // Традиционная культура. № 2. С. 51-62. DOI: https://www.doi.org/10.26158/TK.2020.21.2.005

Будегечиева, Т. Б. (1995) Художественное наследие тувинцев: Судьбы искусств. Жизнь традиции. Диалог культур. От традиционного к современному. М. : Внешторгиздат. 152 с.

Вайнштейн, С. И. (1974) История народного искусства Тувы. М. : Наука. 224 с.

Грязнов, М. П. (1978) Саяно-алтайский олень: (этюд на тему скифо-сибирского звериного стиля) // Проблемы археологии. Вып. ІІ : сб. статей в память профессора М. И. Артамонова. Л. : ЛГУ. 244 с. С. 222-232. 
Грязнов, М. П. (1980) Аржан. Царский курган раннескифского времени. Л. : Наука: Ленингр. отд-ие. 62 с.

Дьяконова, В. П. (1960) Поздние археологические памятники Тувы // Труды ТКАЭЭ. Т. II. С. 348-362.

Замега, Э. (2015) Эпоха бисероплетения // Культурология. № 4 (75). С. 193-196.

Иргит, А. К. (2017) История развития и современное состояние каменной пластики Тувы : дисс. ... кандидата искусствоведения. Барнаул. 216 с.

Калинин, С. С. (2015) «Звериный стиль» пазырыкской скифо-сибирской культуры как культурный код: семиотический анализ // Алтайский текст в русской культуре : сб. науч. ст. / под ред. М. П. Гребневой. Барнаул : Издво АлтГУ. 444 с. С. 201-210.

Канторович, А. Р. (2014) Эволюция и хронология сюжета свернувшегося в кольцо хищника в восточноевропейском скифском зверином стиле // Проблемы истории, филологии, культуры. № 4. С. 66-99.

Канторович, А. Р., Яблонский, Л. Т. (2009) О северопричерноморских и северокавказских параллелях изображениям в скифо-сибирском зверином стиле на предметах из филипповских курганов // Нижневолжский археологический Вестник. № 10. С. 73-99.

Катанов, Н. Ф. (2011) Очерки Урянхайской земли: дневник путешествия, исполненного в 1889 году по поручению императорской академии наук и императорского русского географического общества / под ред. К. А. Бичелдея. Абакан : Журналист. 384 с.

Килуновская, М. Е. (1994) Искусство скифского времени Тувы : типология, периодизация и семантика: дисс... канд. исторических наук. СПб. 283 с.

Килуновская, М. Е. (2015) Памятники декоративно-прикладного искусства из могильников скифского времени в долине р. Ээрбек (Тыва) // Ранний железный век Евразии от архаики до рубежа эр. Центры, периферии и модели культурных взаимодействий. Материалы тематической научной конференции [СПб, 23-27 ноября 2015 г.] / отв. ред. Д. Г. Савинов. СПб. : Скифия-принт. 138 с. С. 42-46.

Киселев, С. В. (1951) Древняя история Южной Сибири / сост. С. Попова. М.: Изд-во Академии наук СССР. 636 с.

Кон, Ф. Я. (1936) За пятьдесят лет / сост. М. Чечановский. М.: Изд-во Советский писатель. Т. 3-4. 332 с.

Красавина, М. В., Балган, А. А. (2019) Тувинское народное прикладное искусство: тенденции развития и современное состояние // Проблемы археологии, этнографии, антропологии Сибири и сопредельных территорий. T. XXV. C. 693-699. DOI: 10.17746/2658-6193.2019.25.693-699

Круглова, А. В. (2020) Художественные языки и коды скифского звериного стиля: ювелирное и декоративноприкладное искусство // Декоративное искусство и предметно-пространственная среда. Вестник МГХПА. № $2-1$. С. 333-343.

Москвина, М. В., Павлова, Е. Ю. (2015) История и основные тенденции художественной обработки металла у тюркско-монгольских народов Сибири // Материалы международной научной конференции, посвященной 25-летию Центра устной истории и этнографии лаборатории исторического краеведения Алтайского государственного педагогического университета / отв. ред. Т. К. Щеглова. Барнаул : Алтайская государственная педагогическая академия. 388 с. С. 289-292.

Неслуховская, А. В. (2016) Традиционные русские женские шейные украшения Верхнеокского региона XIX-XX веков // Ученые записки Орловского государственного университета. № 3 (72). С. $63-68$.

Ондар, А. Б. (2017) Традиционные съемные украшения тувинцев // Успехи современной науки. № 3. С. 41-47.

Панофский, Э. (2009) Этюды по иконологии. Гуманистические темы в искусстве Возрождения / пер. с англ. Н. Г. Лебедевой, Н. А. Осминской. СПб. : Азбука-классика. 418 с.

Переводчикова, Е. В. (1994) Язык звериных образов: очерки искусства Евразийских степей скифской эпохи. М. : Издательская фирма «Восточная литература» РАН. 205 с.

Петрова, А. Г., Соловьева, В. В. (2017) Сравнительный анализ художественного металла тюркских народов Южной Сибири, Средней Азии и якутов // Вестник Арктического государственного института искусств и культуры. № 1 (8). С. 29-34.

Хабарова, М. В. (1981) Народное искусство Якутии. Л. : Изд-во «Художник РСФСР». 142 с.

Чугунов, К. В., Парцингер, Г., Наглер, А. (2004) Золотые звери из долины царей // Открытия российскогерманской археологической экспедиции в Туве / отв. ред. Г. В. Вилинбахов. СПб. : Изд-во Гос. Эрмитажа. 16 с. C. 3-5.

Чугунов, К. В., Парцингер, Ш., Наглер, А. (2017) Царский курган скифского времени Аржан-2 в Туве. Новосибирск : ИАЭТ СО РАН. 500 с. 
Chugunov, K. V. (2017) Early nomads of Central Asia and southern Siberia // The BP exhibition the British Museum, 14.09.2017-14.01.2018. Scythians: warriors of ancient Siberia. Ed. by St John Simpson and Dr Svetlana Pankova. London : Thames \& Hudson Ltd. 368 p. P. 70-86.

Hancar, F. (1952) The Eurasian Animal Style and the Altai Complex//Artibus Asiae Publishers. Vol. 15, No. 1/2. P. $171-194$. Sher, Y. A. (1988) On the Sources of the Scythic Animal Style // Arctic Anthropology. Vol. 25, No. 2. P. 47-60.

Дата поступления: 12.12.2020 г.

\section{REFERENCES}

Ayzhy, Zh. E. and Burbuzhep, D. D. (2019) K voprosu predstavleniia iuvelirnogo iskusstva v Natsional'nom muzee Respubliki Tyva [On the issue of the presentation of jewelry art at the National Museum of the Republic of Tyva]. In: Ermolaevskie chteniia [Ermolaevsky readings]: Proceedings of the $3^{\text {rd }}$ research conference with international participation (May 23-25, 2019), dedicated to the 90th anniversary of the founding of the Aldan-Maadyr National Museum of the Republic of Tuva] / ed. by A. K. Tamdyn. Kyzyl, Tipografiia MBOU KTsO «Anyiak». 256 p. Pp. 193-197. (In Russ.).

Alekseev, A. Yu. (2012) Zoloto skifskikh tsarei v sobranii Ermitazha [The gold of the Scythian Kings in the Hermitage collection]. St. Petersburg, Izd-vo Gos. Ermitazha. 272 p. (In Russ.).

Bravina, R. I. and Ivanova-Unarova, Z. I. (2020) Siianie serebra: traditsionnye ukrasheniia iakutov. Ot istokov k sovremennosti [The glow of silver: Traditional ornaments of the Yakuts from the origins to the present]. Traditsionnaia kul'tura, no. 2, pp. 51-62. (In Russ.). DOI: 10.26158/TK.2020.21.2.005

Budegechi, T. B. (1995) Khudozhestvennoe nasledie tuvintsev [The artistic heritage of Tuvans]. Moscow, Vneshtorgizdat. 151 p. (In Russ.).

Vainshtein, S. I. (1974) Istoriia narodnogo iskusstva Tuvy [A history of folk art in Tuva]. Moscow, Nauka. 223 p. (In Russ.).

Griaznov, M. P. (1978) Saiano-altaiskii olen': (etiud na temu skifo-sibirskogo zverinogo stilia) [The Sayan-Altai deer: a sketch of the Scythian-Siberian animal style)]. In: Problemy arkheologii [Problems of Archeology]. Vol. II : a collection of articles in memory of Professor M. I. Artamonov. Leningrad, LGU. 244 p. Pp. 222-232. (In Russ.).

Griaznov, M. P. (1980) Arzhan. Tsarskii kurgan ranneskifskogo vremeni [Arzhan. The royal kurgan of the Early Scythian time]. Leningrad, Nauka: Leningr. otd-ie. 62 p. (In Russ.).

D'iakonova, V. P. (1960) Pozdnie arkheologicheskie pamiatniki Tuvy [Late archaeological monuments of Tuva]. Trudy TKAEE, vol. II, pp. 348-362. (In Russ.).

Zamega, E. (2015) Epokha biseropleteniia [The epoch of beading]. Kul'turologiia, no. 4 (75), pp. 193-196. (In Russ.).

Irgit, A. K. (2017) Istoriia razvitiia i sovremennoe sostoianie kamennoi plastiki Tuvy [The history of development and the current state of stone statuary in Tuva]: Diss.... Candidate of Arts. Barnaul. 216 p. (In Russ.).

Kalinin, S. S. (2015) «Zverinyi stil'» pazyrykskoi skifo-sibirskoi kul'tury kak kul'turnyi kod: semioticheskii analiz [The "Animal style" of the Pazyryk Scythian-Siberian culture as a cultural code: a semiotic analysis]. In: Altaiskii tekst v russkoi kul'ture [Altay text in Russian culture]: a collection of scientific articles / ed. by M. P. Grebneva. Barnaul, Izd-vo AltGU. 444 p. Pp. 201-210. (In Russ.).

Kantorovich, A. R. (2014) Evoliutsiia i khronologiia siuzheta svernuvshegosia v kol'tso khishchnika v vostochnoevropeiskom skifskom zverinom stile [The evolution and chronology of the motif of coiled-up beast in the Eastern European Scythian animal style]. Problemy istorii, filologii, kul'tury, no. 4, pp. 66-99. (In Russ.).

Kantorovich, A. R. and Yablonskii L. T. (2009) O severoprichernomorskikh i severokavkazskikh paralleliakh izobrazheniiam v skifo-sibirskom zverinom stile na predmetakh iz filippovskikh kurganov [On the Northern Black Sea and North Caucasian parallels to images in the Scythian-Siberian animal style as seen on objects from the Filippovsky mounds]. Nizhnevolzhskii arkheologicheskii vestnik, no. 10, pp. 73-99. (In Russ.).

Katanov, N. F. (2011) Ocherki uriankhaiskoi zemli. Dnevnik puteshestviia, ispolnennogo $v 1889$ godu [Essays on the Uriankhai territory. The diary of a journey made in 1889]. Prep., introduction and comm. by A. K. Kuzhuget. Kyzyl : TIGPI pri Pravitel'stve RT. 383 p. (In Russ.).

Kilunovskaya, M. E. (1994) Iskusstvo skifskogo vremeni Tuvy : tipologiia, periodizatsiia i semantika [The Art of the Scythian time of Tuva: typology, periodization and semantics]: Diss... Candidate of History. St. Petersburg. 283 p. (In Russ.).

Kilunovskaya, M. E. (2015) Pamiatniki dekorativno-prikladnogo iskusstva iz mogil'nikov skifskogo vremeni v doline r. Eerbek (Tyva) [Objects of decorative and applied art from the Scythian-time burial grounds in the valley of the Eerbek River (Tuva)]. In: Rannii zheleznyi vek Evrazii ot arkhaiki do rubezha er. Tsentry, periferii i modeli kul'turnykh vzaimodeistvii [Early Iron Age of Eurasia from the Archaic to the turn of the new era: Centers, peripheries, and models of cultural interactions]. Proceedings of a conference [St. Petersburg, November 23-27, 2015 / ed. by D. G. Savinov. St. Petersburg, Skifiia-print. 138 p. Pp. 42-46. (In Russ.). 
Kiselev, S. V. (1951) Drevniaia istoriia Iuzhnoi Sibiri [The ancient history of southern Siberia] / comp. by S. Popov. Moscow, Izd-vo Akademii nauk SSSR. 636 p. (In Russ.).

Kon, F. Ya. (1936) Za piat'desiat let [In fifty years]. 2nd ed. Vol. 3-4. Moscow, Sovetskii Pisatel' Publ. 344 p. (In Russ.).

Krasavina, M. V. and Balgan, A. A. (2019) Tuvinskoe narodnoe prikladnoe iskusstvo: tendentsii razvitiia i sovremennoe sostoianie [Tuvan folk arts and crafts: trends of development and current state]. Problemy arkheologii, etnografii, antropologii Sibiri i sopredel'nykh territorii, vol. XXV, pp. 693-699. (In Russ.). DOI: 10.17746/2658-6193.2019.25.693-699

Kruglova, A. V. (2020) Khudozhestvennye iazyki i kody skifskogo zverinogo stilia: iuvelirnoe i dekorativno-prikladnoe iskusstvo [Artistic languages and codes of the Scythian animal style: Jewelry art and craft]. Dekorativnoe iskusstvo i predmetno-prostranstvennaia sreda. Vestnik MGKhPA, no. 2-1, pp. 333-343. (In Russ.).

Moskvina, M. V. and Pavlova, E. Yu. (2015) Istoriia i osnovnye tendentsii khudozhestvennoi obrabotki metalla u tiurksko-mongol'skikh narodov Sibiri [History and trends in artistic metalwork of the Turkic-Mongolian peoples of Siberia]. In: Materialy mezhdunarodnoi nauchnoi konferentsii, posviashchennoi 25-letiiu Tsentra ustnoi istorii i etnografii laboratorii istoricheskogo kraevedeniia Altaiskogo gosudarstvennogo pedagogicheskogo universiteta [Proceedings of the international research conference dedicated to the 25th anniversary of the Centre for oral history and Ethnography at the Laboratory of Local history, Altai State Pedagogical University] / ed. by T. K. Shcheglova. Barnaul, Altaiskaia gosudarstvennaia pedagogicheskaia akademiia. 388 p. Pp. 289-292. (In Russ.).

Neslukhovskaia, A. V. (2016) Traditsionnye russkie zhenskie sheinye ukrasheniia Verkhneokskogo regiona XIX-XX vekov [Traditional Russian necklaces of the $19^{\text {th }}-20^{\text {th }}$ centuries from the upper Oka region]. Uchenye zapiski Orlovskogo gosudarstvennogo universiteta, no. 3 (72), pp. 63-68. (In Russ.).

Ondar, A. B. (2017) Traditsionnye s'emnye ukrasheniia tuvintsev [Traditional removable decorations of Tuvan people]. Uspekhi sovremennoi nauki, no. 3, pp. 41-47. (In Russ.).

Panofskii, E. (2009) Etiudy po ikonologii. Gumanisticheskie temy v iskusstve Vozrozhdeniia [Etudes on iconology. Humanistic themes in the art of the Renaissance] / transl. from Engl. by N. G. Lebedeva and N. A. Osminskaya. St. Petersburg, Azbukaklassika. 418 p. (In Russ.).

Perevodchikova, E. V. (1994) Iazyk zverinykh obrazov: ocherki iskusstva Evraziiskikh stepei skifskoi epokhi [The language of animal images: Essays on art of the Eurasian steppes of the Scythian era]. Moscow, Vostochnaia literature Publ. 205 p. (In Russ.).

Petrova, A. G. and Solov'eva, V. V. (2017) Sravnitel'nyi analiz khudozhestvennogo metalla tiurkskikh narodov Yuzhnoi Sibiri, Srednei Azii i iakutov [A comparative analysis of the metalworks of the Turkic peoples of South Siberia, Central Asia and the Yakuts]. Vestnik Arkticheskogo gosudarstvennogo instituta iskusstv i kul'tury, no. 1 (8), pp. 29-34. (In Russ.).

Khabarova, M. V. (1981) Narodnoe iskusstvo Iakutii [Folk art of Yakutia]. Leninrgad, Khudozhnik RSFSR Publ. 142 p. (In Russ.).

Chugunov, K. V., Partsinger, G., Nagler, A. (2004) Zolotye zveri iz doliny tsarei [Golden beasts from the valley of kings]. In: Otkrytiia rossiisko-germanskoi arkheologicheskoi ekspeditsii v Tuve [Discoveries of the Russian-German archaeological expedition in Tuva] / ed. by G. V. Vilinbakhov. St. Petersburg, Izd-vo Gos. Ermitazha. 16 p. Pp. 3-5. (In Russ.).

Chugunov, K. V., Partsinger, Sh. and Nagler, A. (2017) Tsarskii kurgan skifskogo vremeni Arzhan-2 v Tuve [Arzhan II, the royal mound of the Scythian time in Tuva]. Novosibirsk, IAET SO RAN. 500 p. (In Russ.).

Chugunov, K. V. (2017) Early nomads of Central Asia and southern Siberia. In: The BP exhibition the British Museum, 14.09.2017-14.01.2018. Scythians: warriors of ancient Siberia. Ed. by St John Simpson and Dr Svetlana Pankova. London, Thames \& Hudson Ltd. 368 p. Pp. 70-86.

Hancar, F. (1952) The Eurasian Animal Style and the Altai Complex. Artibus Asiae Publishers, vol. 15, no. 1/2, pp. $171-194$. Sher, Y. A. (1988) On the Sources of the Scythic Animal Style. Arctic Anthropology, vol. 25, no. 2, pp. 47-60.

Submission date: 12.12.2020. 